\title{
Human parvovirus B19 interacts with globoside under acidic conditions as an essential step in endocytic trafficking
}

\author{
Jan Bieri $₫$, Remo Leisi $₫$, Cornelia Bircher $\mathbb{D}$, Carlos Ros $\mathbb{D}^{*}$ \\ Department of Chemistry, Biochemistry and Pharmaceutical Sciences, University of Bern, Bern, Switzerland \\ * carlos.ros@dcb.unibe.ch
}

\section{Abstract}

The glycosphingolipid (GSL) globoside (Gb4) is essential for parvovirus B19 (B19V) infection. Historically considered the cellular receptor of $\mathrm{B} 19 \mathrm{~V}$, the role of $\mathrm{Gb} 4$ and its interaction with B19V are controversial. In this study, we applied artificial viral particles, genetically modified cells, and specific competitors to address the interplay between the virus and the GSL. Our findings demonstrate that Gb4 is not involved in the binding or internalization pro-

\section{G OPEn ACCESS}

Citation: Bieri J, Leisi R, Bircher C, Ros C (2021) Human parvovirus B19 interacts with globoside under acidic conditions as an essential step in endocytic trafficking. PLoS Pathog 17(4): e1009434. https://doi.org/10.1371/journal. ppat. 1009434

Editor: Patrick Hearing, Stony Brook University, UNITED STATES

Received: February 26, 2021

Accepted: April 12, 2021

Published: April 20, 2021

Peer Review History: PLOS recognizes the benefits of transparency in the peer review process; therefore, we enable the publication of all of the content of peer review and author responses alongside final, published articles. The editorial history of this article is available here: https://doi.org/10.1371/journal.ppat.1009434

Copyright: @ 2021 Bieri et al. This is an open access article distributed under the terms of the Creative Commons Attribution License, which permits unrestricted use, distribution, and reproduction in any medium, provided the original author and source are credited.

Data Availability Statement: All relevant data are within the manuscript and its Supporting information files. cess of the virus into permissive erythroid cells, a function that corresponds to the VP1u cognate receptor. However, Gb4 is essential at a post-internalization step before the delivery of the single-stranded viral DNA into the nucleus. In susceptible erythroid Gb4 knockout cells, incoming viruses were arrested in the endosomal compartment, showing no cytoplasmic spreading of capsids as observed in Gb4-expressing cells. Hemagglutination and binding assays revealed that $\mathrm{pH}$ acts as a switch to modulate the affinity between the virus and the GSL. Capsids interact with Gb4 exclusively under acidic conditions and dissociate at neutral $\mathrm{pH}$. Inducing a specific Gb4-mediated attachment to permissive erythroid cells by acidification of the extracellular environment led to a non-infectious uptake of the virus, indicating that low $\mathrm{pH}$-mediated binding to the GSL initiates active membrane processes resulting in vesicle formation. In summary, this study provides mechanistic insight into the interaction of B19V with Gb4. The strict pH-dependent binding to the ubiquitously expressed GSL prevents the redirection of the virus to nonpermissive tissues while promoting the interaction in acidic intracellular compartments as an essential step in infectious endocytic trafficking.

\section{Author summary}

The neutral glycosphingolipid globoside (Gb4) has been historically considered the cellular receptor of $\mathrm{B} 19 \mathrm{~V}$, however, its wide expression profile does not correlate well with the restricted tropism of the virus. Here, we show that $\mathrm{Gb} 4$ is essential for the infection at a step following virus uptake and before the delivery of the viral ssDNA into the nucleus. B19V interacts with Gb4 exclusively under acidic conditions, prohibiting the interaction on the plasma membrane and promoting it inside the acidic endosomal compartments, which are engaged by the virus and the GSL after internalization. In the absence of Gb4, 
Funding: This study was supported by a grant from the Swiss National Science Foundation (grant 31003A_179384 to J.B.). www.snf.ch. The funders had no role in study design, data collection and analysis, decision to publish, or preparation of the manuscript.

Competing interests: The authors have declared that no competing interests exist. incoming viruses are retained in the endocytic compartment and the infection is aborted. This study reveals the mechanism of the interaction between the virus and the glycosphingolipid and redefines the role of Gb4 as an essential intracellular partner required for infectious entry.

\section{Introduction}

Parvovirus B19 (B19V) is a human pathogen discovered in 1974 [1]. The virus causes infections worldwide that vary in severity depending on the age as well as the immunologic and hematologic status of the host [2,3]. In healthy children, B19V causes a mild disease named erythema infectiosum or fifth disease [4]. The virus can occasionally lead to more severe complications, such as arthropathies in adults [5], hydrops fetalis in pregnant women [6] and chronic red cell aplasia in patients with underlying hemolytic anemia $[7,8]$. The linear singlestranded DNA genome of 5.6-kb in length is encapsidated within a small, non-enveloped, icosahedral particle consisting of 60 structural proteins, VP1 and VP2 [9]. These proteins share the same sequence except for an additional amino-terminal VP1 unique region (VP1u) of 227 amino acids. VP1u harbors strong neutralizing epitopes and is crucial to elicit an efficient immune response against the virus [10]. The two most relevant domains in the VP1u is a receptor binding domain (RBD) required for virus uptake into host cells [11] and a phospholipase $\mathrm{A} 2\left(\mathrm{PLA}_{2}\right)$ domain required for the infection [12-15], presumably to promote endosomal escape [16].

$\mathrm{B} 19 \mathrm{~V}$ is transmitted primarily via the respiratory route [5]. From the respiratory epithelium, the virus particles access the bloodstream by an unknown mechanism. A striking feature of B19V is its marked tropism for erythroid progenitor cells (EPCs) in the bone marrow [1719]. The lytic replication of the virus in this cell population accounts for the hematological disorders typically associated with the infection. The distribution of specific cellular receptors in concert with essential intracellular factors explains the remarkable narrow tropism of B19V [19-22].

Historically, the neutral glycosphingolipid (GSL) globoside (Gb4) or P antigen has been considered the primary cellular receptor of B19V [23]. Gb4 is expressed in target EPCs and the virus exhibits hemagglutinating activity, which can be inhibited by soluble or lipid-associated Gb4 $[24,25]$. The rare persons lacking Gb4 (p phenotype) are naturally resistant to the infection and their erythrocytes cannot be hemagglutinated by the virus [26]. Despite the solid evidence, the role of $\mathrm{Gb} 4$ as the cellular receptor of $\mathrm{B} 19 \mathrm{~V}$ has been increasingly questioned. The restricted tropism of B19V [17-19] does not align well with the wide expression profile of Gb4 $[27,28]$. Gb4 is the most abundant neutral GSL expressed on the membranes of human red blood cells (RBCs) [29,30], which cannot be productively infected. Moreover, the degree of virus attachment to cells does not correspond with the expression levels of Gb4, and although the presence of $\mathrm{Gb} 4$ was shown to be essential for the infection, it was not enough for productive infection [31].

The fact that the virus cannot internalize certain cells despite the expression of Gb4, suggests that other receptor molecules must be required for the uptake of the virus into susceptible cells. In line with this assumption, we showed that VP1u is required for virus uptake and identified a functional RBD at the most amino-terminal part of the protein, which mediates virus uptake independently of the rest of the capsid [11,19,32]. Different from Gb4, the expression profile of the VP1u cognate receptor (VP1uR) corresponds to the narrow tropism of B19V, limiting virus internalization and infection exclusively in cells at erythropoietin-dependent 
erythroid differentiation stages $[19,33]$. Although VP1u is not accessible in native capsids, interaction with surface receptors on susceptible cells renders VP1u accessible $[34,35]$. This process could be partially reproduced by incubation of native capsids with soluble Gb4 [36], suggesting that the neutral GSL may assist the uptake process. However, in a recent study, we showed that in susceptible erythroid cells expressing VP1uR and lacking Gb4, VP1u becomes exposed and the virus is internalized, highlighting the irrelevance of $\mathrm{Gb} 4$ in this process. However, Gb4 was found to be essential for the internalized virus to initiate the infection [37].

It remains unclear whether $\mathrm{B} 19 \mathrm{~V}$ requires $\mathrm{Gb} 4$ as a host cell binding partner, or indirectly as a signaling molecule or cellular component required for the infection. The hemagglutination of human erythrocytes by B19V [24], which express large quantities of Gb4 [29,30], and the hemagglutination inhibition in the presence of soluble Gb4 [25], strongly indicate that $\mathrm{B} 19 \mathrm{~V}$ interacts with Gb4. However, attempts to confirm the interaction have not yet been conclusive. The binding of B19 virus-like particles (VLPs) to Gb4 in supported lipid bilayers has been reported [38], and the complex has been observed by cryoEM image reconstruction [39]. However, other studies using a higher resolution cryoEM failed to confirm the interaction [25]. In the same study, no binding signals above background controls were detected in various highly sensitive assays employing fluorescence-labeled liposomes, radiolabeled B19 capsids, surface plasmon resonance, and isothermal titration microcalorimetry [25]. These inconsistent observations suggest that either the interaction between B19V and Gb4 does not occur or requires specific conditions that have not yet been identified.

In this study, we have addressed the interplay between B19V and Gb4, the conditions required for the interaction, and the infection step where the GSL is essential. To this end, the hemagglutinating activity and adsorption capacity of native virions and virus-like particles (VLPs) to Gb4 expressed on human erythrocytes and erythroleukemia cells were examined under different experimental conditions. The role of $\mathrm{Gb} 4$ was investigated by following the infection of native virus and engineered capsids, differing in their capacity to interact with Gb4, in wild-type and Gb4 knockout erythroid cells. The study confirms the binding of B19V to Gb4, identifies the strict conditions modulating the interaction and redefines the essential role of the GSL at a post-internalization step for the infectious trafficking of the incoming virus.

\section{Results}

\section{Gb4 is essential at a post-internalization step and before the delivery of the viral genome into the nucleus for replication}

In an earlier study, we established a Gb4 knockout (KO) UT7/Epo cell line and demonstrated that $\mathrm{Gb} 4$ is essential for productive infection, but it is not required for virus attachment and internalization, which is mediated by the VP1u cognate receptors (VP1uR) [32,37]. Here, we used a recombinant VP1u construct (S1A and S1B Fig) to demonstrate that VP1uR expression is not altered in Gb4 KO cells. The expression of VP1uR in cells was sufficient to trigger virus attachment and uptake, however, in the absence of Gb4, the intracellular capsids failed to initiate the infection (Fig $1 \mathrm{~A}$ and S2 Fig). In sharp contrast, blocking VP1uR by pre-incubation of cells with recombinant VP1u abolished attachment and internalization (Fig 1B).

To test the capacity of VP1uR to mediate virus internalization without the involvement of Gb4 or any other additional receptor(s) or attachment factor(s), recombinant VP1u subunits were chemically coupled to bacteriophage MS2 capsids, as previously described with some modifications [19] (S1C and S1D Fig). The engineered capsids were incubated with wild-type (WT) or with Gb4 KO UT7/Epo cells for $1 \mathrm{~h}$ at $4^{\circ} \mathrm{C}$ for virus attachment or at $37^{\circ} \mathrm{C}$ for virus internalization. Regardless of the presence or absence of Gb4, the VP1u decorated particles 

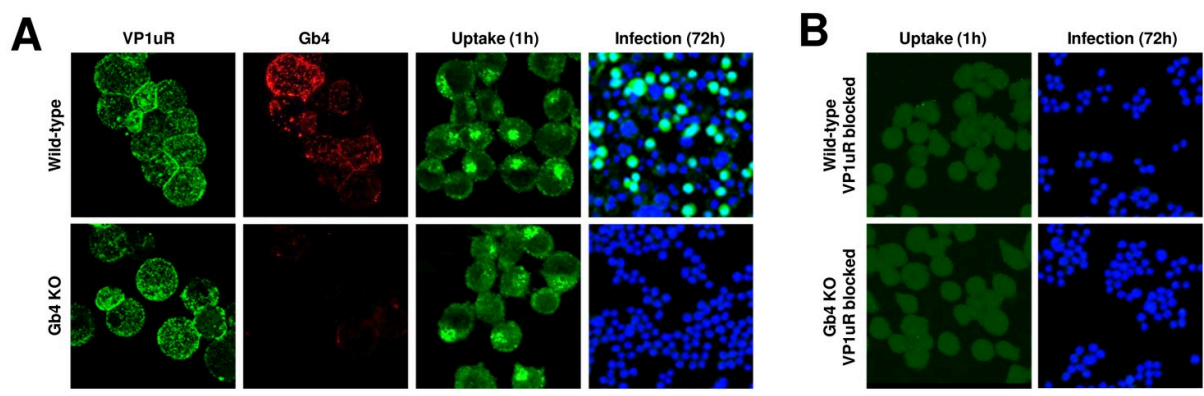

C
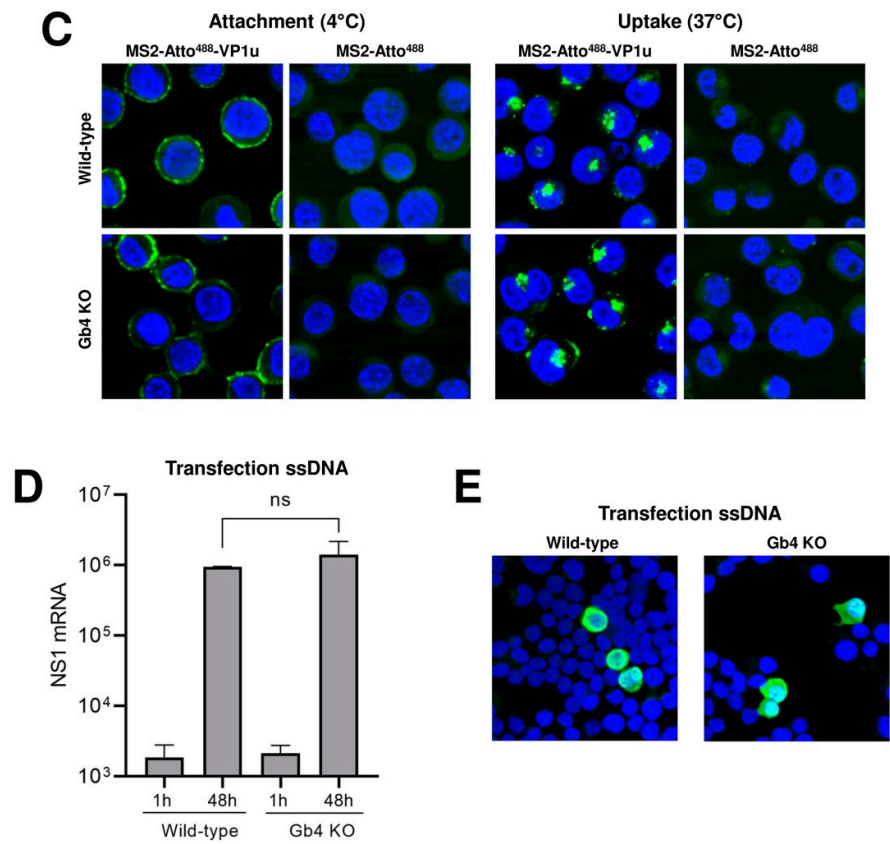

Fig 1. Gb4 is essential at a post-internalization step and before the delivery of the viral genome into the nucleus for replication. (A) Detection of VP1u cognate receptor (VP1uR) and Gb4 in UT7/Epo wild-type (WT) and Gb4 knockout (KO) cells by immunofluorescence (IF). Cells were incubated with either recombinant VP1u labelled with anti-FLAG antibody or anti-Gb4 antibody, washed, fixed and stained with secondary antibodies for confocal microscopy. $\mathrm{B} 19 \mathrm{~V}$ uptake $\left(1 \mathrm{~h}\right.$ at $\left.37^{\circ} \mathrm{C}\right)$ was detected with the antibody $860-55 \mathrm{D}$ against intact capsids, while progeny virus $\left(72 \mathrm{~h}\right.$ at $\left.37^{\circ} \mathrm{C}\right)$ was detected with the antibody $3113-81 \mathrm{C}$ against viral capsid proteins. (B) B19V uptake (1h) and infection (72h) in cells pre-incubated with recombinant VP1u (VP1u $\Delta \mathrm{C} 126)$ (S1 Fig) for $30 \mathrm{~min}$ at $4^{\circ} \mathrm{C}$ to block the VP1uR. (C) Attachment $\left(1 \mathrm{~h} \mathrm{at} 4^{\circ} \mathrm{C}\right)$ and uptake $\left(1 \mathrm{~h}\right.$ at $\left.37^{\circ} \mathrm{C}\right)$ of fluorescently labelled (Atto 488$)$ MS2 bacteriophage capsids with conjugated recombinant VP1u $\Delta \mathrm{C} 126$ from B19V (MS2-Atto ${ }^{488}$-VP1u) (S1 Fig). As a control, unconjugated fluorescently labelled MS2 bacteriophage capsids were used (MS2-Atto ${ }^{488}$ ). Nuclei were stained with DAPI. (D) NS1 mRNA quantification by RT-qPCR after transfection of genomic ssDNA (1h and 48h) in WT and Gb4 $\mathrm{KO}$ cells. The results are presented as the mean \pm SD of three independent experiments. ns, not significant. (E) Detection of capsid protein expression (3113-81C; green) after transfection of genomic ssDNA (48h) in WT and Gb4 KO cells.

https://doi.org/10.1371/journal.ppat.1009434.g001

were able to bind and internalize into the cells without detectable differences (Fig 1C). This result indicates that virus uptake is activated by the interaction of VP1u with VP1uR, without the contribution of other capsid regions.

To better define the step of the infection where Gb4 is required, the viral ssDNA genome was extracted from native virions and directly introduced into the cells by transfection. This approach allows bypassing the cytoplasmic trafficking steps but not the second-strand synthesis, which is the first step in viral DNA replication. As shown in Fig 1D, a similar amount of 
NS1 mRNAs was detected in transfected WT and Gb4 KO cells. The capacity of B19V to infect Gb4 KO cells following transfection was further confirmed by immunofluorescence microscopy with an antibody against viral capsid proteins (Fig 1E). These results together indicate that $\mathrm{Gb} 4$ is not required for virus attachment and uptake, but instead plays an essential role at an intracellular trafficking step before the delivery of the viral genome into the nucleus for replication.

\section{In the absence of $\mathrm{Gb} 4$, internalized $\mathrm{B} 19 \mathrm{~V}$ is arrested in the endosomal compartment}

Following interaction with VP1uR, B19V is internalized by clathrin-mediated endocytosis and rapidly spreads throughout the early-late endosomes and lysosomes [32,40]. Thereafter, capsids move progressively from the endo-lysosomal compartment, which typically appears as a dense perinuclear signal, to a more dispersed spatial arrangement with limited or no co-localization with endo-lysosomal markers [40]. To further circumscribe the trafficking step where $\mathrm{Gb} 4$ is required, we followed the intracellular progression of the virus in the presence (WT cells) or absence of Gb4 (Gb4 KO cells) by immunofluorescence microscopy with antibodies targeting B19V capsids (860-55D) and endo-lysosomal markers (M6PR and Lamp1). The results revealed a striking difference depending on the presence or absence of Gb4. As expected, at 30 min post-infection (pi), B19V co-localized with late endosomes and lysosomes in WT and Gb4 KO cells. At 3h pi, co-localization of incoming viruses with endo-lysosomal markers decreased in WT cells and their clustered spatial distribution changed to a more scattered arrangement. In contrast, in cells lacking $\mathrm{Gb} 4$, the internalized virus did not show the same progression and remained associated with the endo-lysosomal markers, showing no cytoplasmic spreading of capsids as observed in Gb4-expressing cells (Fig 2A). The distinct endocytic progression of incoming capsids in presence or absence of Gb4 was further confirmed by quantitative analysis of intracellular fluorescent foci per cell (Fig 2B and S3 Fig).

This observation suggests a role of the GSL in the infectious endocytic trafficking of B19V. To further corroborate this assumption, we compared the endocytic trafficking of native B19V and MS2-VP1u particles. Similar to B19V, MS2-VP1u can internalize into the host cell through VP1uR interaction, however, these artificial capsids lack potential interaction sites harbored in the B19 capsid structure, such as a putative Gb4 binding site. Besides, MS2-VP1u lacks the $\mathrm{PLA}_{2}$ domain, which is required for endosomal escape [16,41] (S1A Fig). Accordingly, following uptake these particles remained steadily associated with endo-lysosomal markers (S4 Fig). WT and Gb4 KO cells were infected with $\mathrm{B} 19 \mathrm{~V}$ for $30 \mathrm{~min}$ at $37^{\circ} \mathrm{C}$ to allow virus internalization followed by incubation with MS2-VP1u for an additional $1 \mathrm{~h}$ at $37^{\circ} \mathrm{C}$. At $3 \mathrm{~h} \mathrm{pi}$, the cells were examined by confocal immunofluorescence microscopy. In WT cells, B19V and MS2-VP1u had a different distribution with limited co-localization. B19V appeared more scattered, while MS2-VP1u exhibited the characteristic endo-lysosomal distribution. In cells lacking Gb4, both B19V and MS2-VP1u displayed the same intracellular distribution with a strong co-localization (Fig 2C). The scattered signal observed at $3 \mathrm{~h}$ pi in WT cells did not co-localize with early-late endosomes (EEA1, M6PR), lysosomes (Lamp1), recycling endosomes (Rab11), Golgi apparatus (Giantin) or trans-Golgi network (TGN46), however, it co-localized partially with the cis-Golgi marker GM130 (Fig 2D).

\section{B19V interacts with soluble and membrane-associated Gb4 in a pH- dependent manner}

Various studies conducted to investigate the binding of B19V with Gb4 generated contradictory results, which was attributed to the rigorous conditions required for the interaction 
A
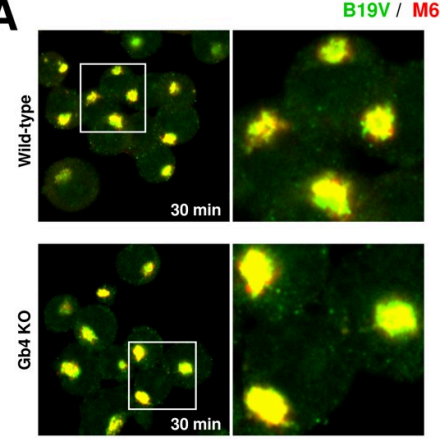

C
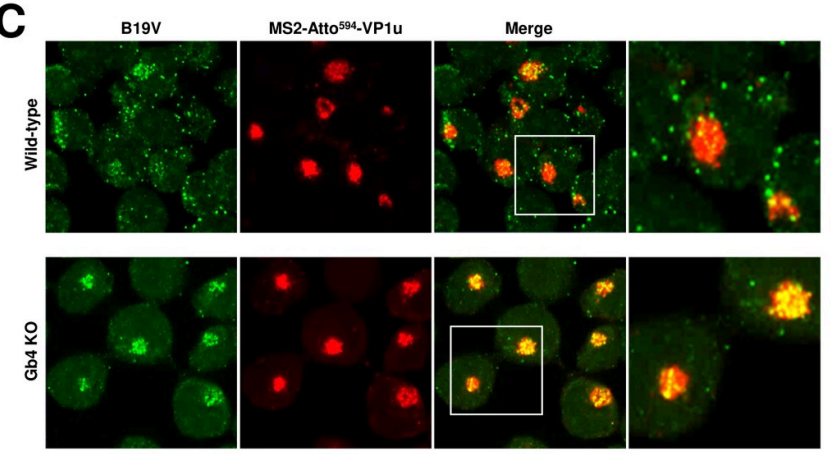
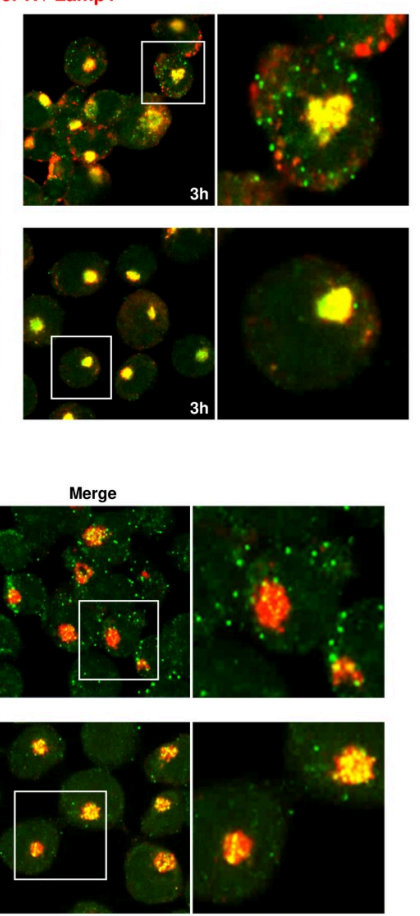

B

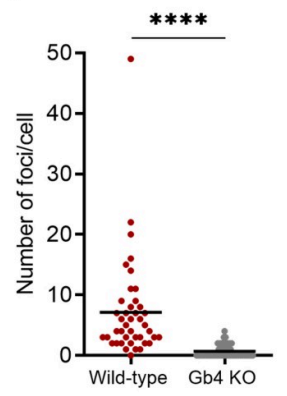

D

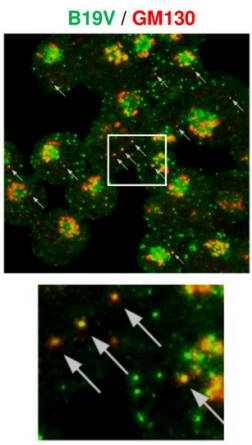

Fig 2. In the absence of Gb4, internalized $\mathrm{B} 19 \mathrm{~V}$ is arrested in the endosomal compartment. (A) Co-localization of incoming B19V capsids (860-55D; green) with endo-lysosomal markers (M6PR and Lamp1; red) in UT7/Epo WT and Gb4 KO cells at $30 \mathrm{~min}$ and $3 \mathrm{~h}$ pi. (B) Quantitative analysis of scattered cytoplasmic foci (B19V capsid signal) not colocalizing with endocytic markers at $3 \mathrm{~h}$ pi (S3 Fig). Unpaired Students t-test with Welch's correction (not assuming same SD) was used for statistical comparison. ****, $p<0.0001$. (C) Co-localization of incoming B19V capsids (860-55D; green) with MS2-Atto ${ }^{594}$-VP1u in UT7/Epo WT and Gb4 KO cells at 3h pi. (D) Co-localization of B19V capsids (860$55 \mathrm{D}$; green) with a cis-Golgi marker (GM130; red) in WT cells at $3 \mathrm{~h}$ pi.

https://doi.org/10.1371/journal.ppat.1009434.g002

$[23,25,38]$. The endosomal retention of incoming capsids in cells lacking Gb4 suggests a possible interaction inside acidic endosomes, which are engaged by both the virus and the GSL shortly after internalization $[40,42]$. To test this hypothesis, the interaction with Gb4 expressed on human red blood cells (RBCs) was examined under characteristic acidic endosomal conditions. Interestingly, hemagglutination by $\mathrm{B} 19 \mathrm{~V}$ is routinely performed at low $\mathrm{pH}$ because it enhances the reaction $[24,43]$, however, the underlying mechanism has not been elucidated. Inspired by this phenomenon, the hemagglutinating activity and the binding capacity of the virus to $\mathrm{RBCs}$ were quantitatively analyzed under a wide range of $\mathrm{pH}$ conditions. As shown in Fig 3A, hemagglutination of RBCs by B19V occurs exclusively under acidic conditions $(\mathrm{pH}<6.4)$. In contrast, hemagglutination with equal amounts of minute virus of mice (MVM), a parvovirus that binds sialic acid on erythrocytes, is not influenced by $\mathrm{pH}$. Increasing the number of B19 virions did not influence the results (Fig 3B). Accordingly, the low pHdependent hemagglutination of RBCs by $\mathrm{B} 19 \mathrm{~V}$ is due to the intrinsic nature of the interaction between the virus and Gb4. As a control, the visualization of RBCs at neutral or acidic conditions by scanning electron microscopy did not reveal detectable differences in cell integrity (S5 Fig).

To confirm that the hemagglutination is caused by the interaction of the virus with Gb4, the binding of B19V to RBCs was quantified in the presence of soluble Gb4. Globotriaosylceramide (Gb3), which is the precursor of $\mathrm{Gb} 4$ was used as a control. Compared to $\mathrm{pH}$ 7.4, a sharp increase $(>2 \log 10)$ in the binding of $\mathrm{B} 19 \mathrm{~V}$ to RBCs was observed at $\mathrm{pH}$ 6.3. While the 
A

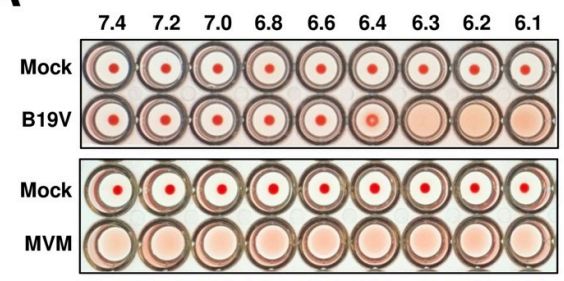

B $\mathrm{pH}$

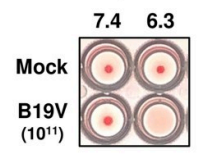

C
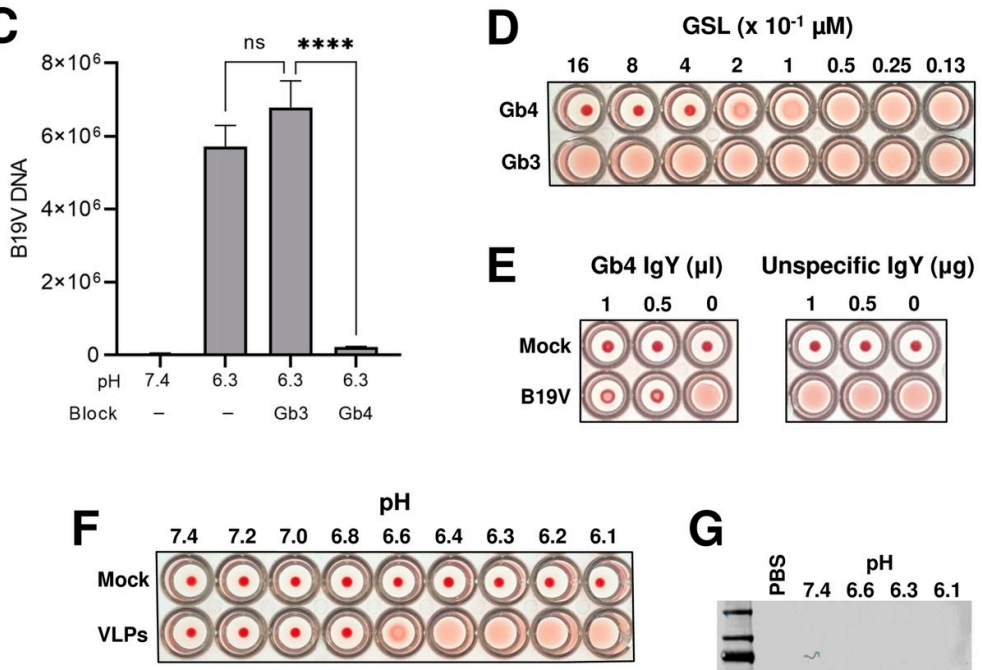

H

GSL $\left(x 1^{-1} \mu \mathrm{M}\right)$
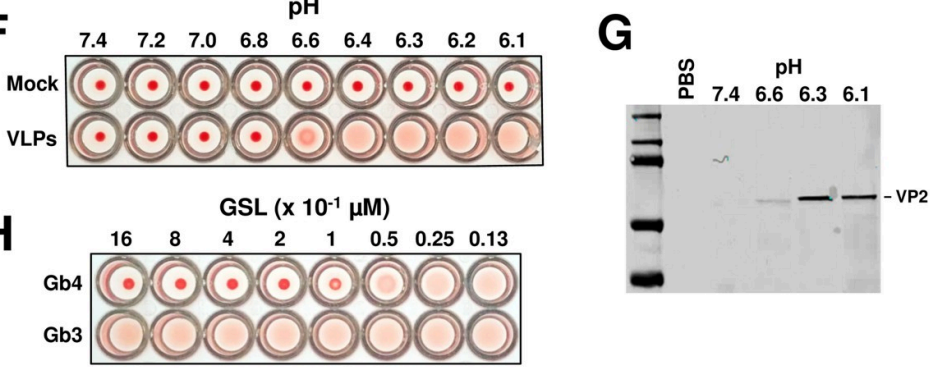

Fig 3. B19V interacts with soluble and membrane Gb4 in a pH-dependent manner. (A) Hemagglutination of human RBCs $(0.5 \%$ in $100 \mu \mathrm{liBS})$ by B19V or MVM $\left(5 \times 10^{9}\right)$ at different pH values. (B) Hemagglutination of RBCs with a 20 -fold increase of $\mathrm{B} 19 \mathrm{~V}$ particles at $\mathrm{pH} 7.4$ and 6.3. (C) Quantitative analysis of B19V binding to RBCs at $\mathrm{pH}$ 7.4 and 6.3 in the presence or absence of GSLs (Gb3 or Gb4). Virus $\left(5 \times 10^{9}\right)$ was incubated directly with RBCs $(0.5 \%$ in $100 \mu \mathrm{PiBS}$ ) at the indicated $\mathrm{pH}$ or pre-blocked with $5 \times 10^{14}$ molecules $(\mathrm{Gb} 3$ or $\mathrm{Gb} 4)$ for $1 \mathrm{~h}$ at $\mathrm{pH} 6.3$ prior to incubation with RBCs. After $1 \mathrm{~h}$ at room temperature, the erythrocytes were washed four times with the corresponding buffer and the viral DNA was extracted and quantified. The results are presented as the mean \pm SD of three independent experiments. ${ }^{* * * *}, p<0.0001$; ns, not significant. (D) Hemagglutination inhibition test in the presence or absence of different amount (0.013-1.6 $\mu \mathrm{M}$ ) of GSLs (Gb3 or Gb4) at pH 6.3. (E) Hemagglutination inhibition test in the presence of anti-Gb4 or non-specific IgY antibodies at $\mathrm{pH} 6.3$ (antibodies were incubated with RBCs $1 \mathrm{~h}$ before adding the virus). (F) Hemagglutination of RBCs $(0.5 \%$ in $100 \mu \mathrm{l} \mathrm{PiBS})$ by VLPs $\left(5 \times 10^{9}\right)$ at different $\mathrm{pH}$ values. (G) Detection of VLPs bound to RBCs at different $\mathrm{pH}$ values by Western blot using antibody $3113-81 \mathrm{C}$. (H) Hemagglutination inhibition test in the presence or absence of different amount $(0.013-1.6 \mu \mathrm{M})$ of $\mathrm{Gb} 3$ or Gb4 at $\mathrm{pH}$ 6.3 .

https://doi.org/10.1371/journal.ppat.1009434.g003

presence of soluble $\mathrm{Gb} 3$ did not prevent the interaction, a significant inhibition of the binding was observed in the presence of soluble Gb4 (Fig 3C). Confirming this observation, Gb4 (>0.2-0.4 $\mu \mathrm{M}$ ) but not Gb3 inhibited hemagglutination of RBCs in a dose-dependent manner (Fig 3D). Likewise, hemagglutination was inhibited in the presence of a specific antibody against Gb4 (Fig 3E).

To verify that binding to $\mathrm{Gb} 4$ is exclusively due to a $\mathrm{pH}$-mediated capsid rearrangement, the interaction was also tested with B19 virus-like particles (VLPs) consisting of VP2 (VP2-only particles). Recombinant baculoviruses that express VP2-only VLPs were prepared using the Bac-to-Bac system. The purity of the VP2 particles was verified by SDS-PAGE and 
their integrity was examined by electron microscopy and by dot blot with an antibody against intact capsids (S6 Fig). Similar to the plasma-derived B19V, hemagglutination of erythrocytes by VLPs was also $\mathrm{pH}$-dependent (Fig 3F). A minor shift in the $\mathrm{pH}$ required for hemagglutination between VLPs (6.4 full, 6.6 partial) and B19V (6.3 full, 6.4 partial) was observed. Since the accurate quantification of B19V by PCR is not possible for VLPs, this minor variation might be explained by differences in the number of particles applied. The $\mathrm{pH}$-dependent binding of VLPs to erythrocytes was examined by Western blot with an antibody against VP2. The binding at the different $\mathrm{pH}$ values correlated well with the HA (Fig 3G). Similar to native B19V, hemagglutination by VLPs was inhibited in a dose-dependent manner by $\mathrm{Gb} 4$ but not by $\mathrm{Gb} 3$ (Fig $3 \mathrm{H}$ ). Together, these results demonstrate that $\mathrm{B} 19 \mathrm{~V}$ does not bind to $\mathrm{Gb} 4$ expressed on cellular membranes, which are typically exposed to neutral $\mathrm{pH}$ conditions. The interaction occurs exclusively under acidic conditions and is mediated by the VP2 region of the capsid.

\section{Different to the extracellular environment, the early endosomal compartment provides optimal conditions for Gb4 interaction}

$\mathrm{B} 19 \mathrm{~V}$ binding to $\mathrm{Gb} 4$ expressed on human erythrocytes was tested at various $\mathrm{pH}$ conditions and quantified by qPCR. The results revealed a progressive increase in affinity at decreasing $\mathrm{pH}$ values, reaching a maximum at $\mathrm{pH} 6.0$ (Fig $4 \mathrm{~A}$ ), which corresponds to the average $\mathrm{pH}$ measured in early endosomes $[44,45]$. At neutral $\mathrm{pH}$, the binding affinity decreased more than 3 logs to background levels, confirming that $\mathrm{B} 19 \mathrm{~V}$ does not recognize Gb4 expressed on the plasma membrane.

Parvovirus capsid proteins are fine-tuned to rearrange in response to $\mathrm{pH}$ conditions, but also to other cellular cues encountered during entry. Besides the low $\mathrm{pH}$, early endosomes are characterized by a depleted $\mathrm{Ca}^{2+}$ environment $[46,47]$. Divalent cations have been shown to play important roles in the capsid stability of parvoviruses and their depletion can trigger structural rearrangements and alter capsid integrity [48-50]. The influence of divalent cations in the interaction was examined at $\mathrm{pH}$ 6.3, which is close to the hemagglutination threshold and therefore more sensitive to affinity fluctuations between the virus and the GSL. Neither the sequestration of $\mathrm{Ca}^{2+}$ by EGTA or $\mathrm{Mg}^{2+}$ by EDTA nor their addition influenced the low $\mathrm{pH}$-dependent hemagglutination activity of B19V. The HA was also undisturbed in a complex solution, such as cell culture media (MEM, minimal essential medium) (Fig 4B). Low pH-
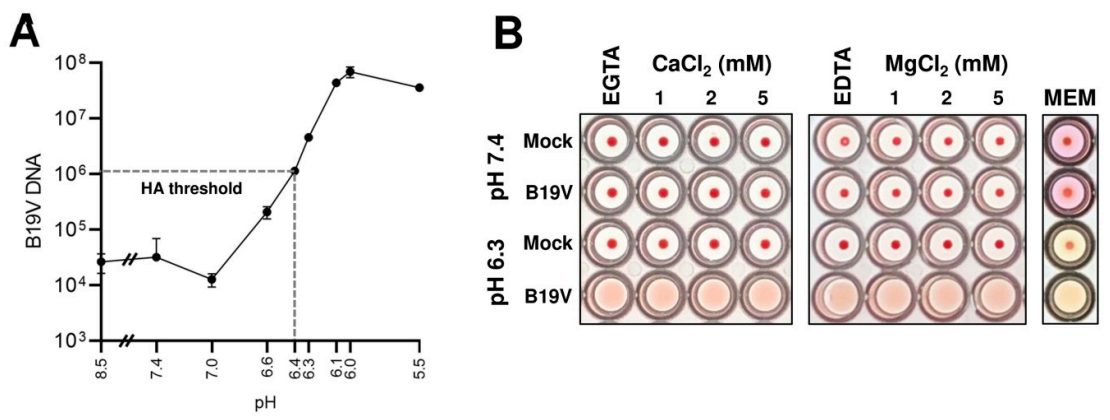

Fig 4. Determination of the optimal conditions required for $\mathrm{B} 19 \mathrm{~V}$ and $\mathrm{Gb} 4$ interaction. (A) Determination of the optimal $\mathrm{pH}$ for $\mathrm{B} 19 \mathrm{~V}$ binding to $\mathrm{Gb} 4$. RBCs $(0.5 \%$ in $100 \mu \mathrm{PiBS})$ were incubated with $\mathrm{B} 19 \mathrm{~V}\left(5 \times 10^{9}\right)$ at $\mathrm{pH}$ values ranging from 8.5 to 5.5 . After $1 \mathrm{~h}$, cells were washed in the corresponding buffer, and viral DNA was extracted and quantified by qPCR. (B) Hemagglutination at neutral (7.4) or acidic (6.3) $\mathrm{pH}$ was carried out in the presence of divalent cations $\left(\mathrm{Ca}^{2+}\right.$ or $\mathrm{Mg}^{2+}$ ), chelating agents (5 mM EGTA or EDTA) or in minimal essential medium (MEM). $\mathrm{B} 19 \mathrm{~V}$ was incubated with the different buffers for $1 \mathrm{~h}$ before incubation with the erythrocytes. HA, hemagglutination assay.

https://doi.org/10.1371/journal.ppat.1009434.g004 
mediated binding of B19V to Gb4 was also independent of the temperature (S7 Fig). These results indicate that contrary to the extracellular milieu, the conditions found in the early endosomal compartment are optimal for the interaction between incoming viruses and $\mathrm{Gb} 4$.

\section{$\mathrm{pH}$ acts as a switch to regulate the affinity between $\mathrm{B} 19 \mathrm{~V}$ and $\mathrm{Gb} 4$}

The interaction of viruses with cellular partners is highly dynamic and influenced by the different environmental conditions encountered during the process of entry, resulting in affinity fluctuations. These affinity changes are finely tuned to promote binding or dissociation with the target molecules. During entry, B19V is initially exposed to the acidic conditions of the endosomal compartment, followed by the neutral $\mathrm{pH}$ of the cytosol, where the dissociation from the GSL would facilitate the virus targeting to the nucleus. To investigate $\mathrm{pH}$-dependent changes in binding affinity, the dissociation of B19V from Gb4 expressed on human erythrocytes was examined by adjusting the $\mathrm{pH}$ from 6.3 to 7.4 . As shown in Fig $5 \mathrm{~A}$, more than $95 \%$ of the particles bound to $\mathrm{Gb} 4$ on erythrocyte membranes at $\mathrm{pH} 6.3$ dissociated when the $\mathrm{pH}$ was restored to 7.4. Moreover, preincubation of viruses or RBCs separately at $\mathrm{pH} 6.3 \mathrm{did}$ not allow hemagglutination at neutral $\mathrm{pH}$ (S8 Fig). Additionally, the reversibility of the interaction was tested by direct visualization of the hemagglutination reaction with VLPs. Under light microscopy, the erythrocytes appeared dispersed at $\mathrm{pH} 7.4$ and formed large clusters at $\mathrm{pH}$ 6.3, conforming with the HA. The erythrocyte clusters were not detected when the acidic $\mathrm{pH}$ was neutralized (Fig 5B), indicating that binding of VLPs to Gb4 is also reversible.

Although the interaction is reversible, binding of $\mathrm{B} 19 \mathrm{~V}$ to $\mathrm{Gb} 4$ may trigger irreversible capsid conformational changes that prepare the virus for subsequent infection steps or even render the incoming capsids independent of Gb4. To test this hypothesis, viruses bound to Gb4 at low $\mathrm{pH}$ were released by exposure to neutral $\mathrm{pH}$ and used to infect WT and $\mathrm{Gb} 4 \mathrm{KO}$ cells. The previous interaction of the virus with $\mathrm{Gb} 4$ on the surface of $\mathrm{RBCs}$ at low $\mathrm{pH}$ changed neither their capacity to infect WT cells nor their inability to infect Gb4 KO cells (Fig 5C). These results together reveal that $\mathrm{pH}$ acts as a regulatory switch, modulating the affinity between the virus and the GSL.
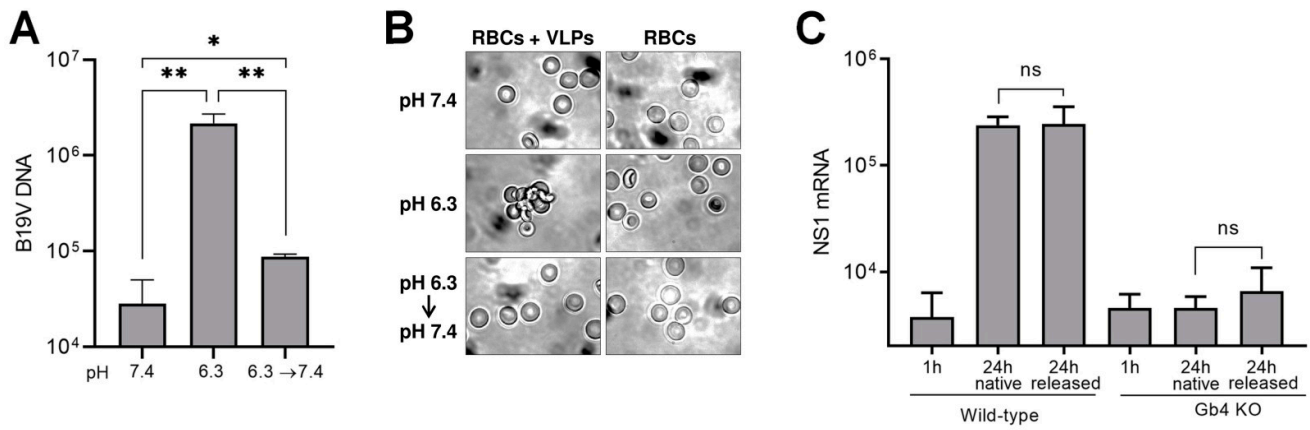

Fig 5. $\mathrm{pH}$ acts as an affinity switch to regulate binding and dissociation between $\mathrm{B} 19 \mathrm{~V}$ and Gb4. (A) B19V (510 $)$ was incubated with RBCs $(0.5 \%$ in $100 \mu \mathrm{l} \mathrm{PiBS})$ for $1 \mathrm{~h}$ at $\mathrm{pH} 7.4$ or 6.3 . The cell suspensions were washed twice with a buffer of the same $\mathrm{pH}$, except for one sample incubated at $\mathrm{pH} 6.3$ and washed at $\mathrm{pH}$ 7.4. RBCs were incubated 30 additional minutes in the washing buffer at room temperature, washed twice, and viral DNA was extracted and quantified by qPCR. The results are presented as the mean \pm SD of three independent experiments. ${ }^{*}, p<0.05 ;{ }^{* *}$, $p<0.01$. (B) Visualization of the hemagglutination reaction by VLPs. RBCs were incubated with VLPs $\left(510^{9}\right)$ at $p H 7.4$ or 6.3 for $1 \mathrm{~h}$ at room temperature. Prior to visualization by phase contrast microscopy, the samples were diluted with a buffer of the same $\mathrm{pH}$ or neutralized to $\mathrm{pH}$ 7.4. (C) Infectivity of Gb4-dissociated virus. Viruses bound to RBCs at $\mathrm{pH}$ 6.3 and dissociated at $\mathrm{pH} 7.4$ were quantified by qPCR. Equal amounts of native and Gb4-dissociated virus were added to UT7/Epo WT or Gb4 KO cells. After $1 \mathrm{~h}$ or $24 \mathrm{~h}$, cells were washed four times and NS1 mRNA was extracted and quantified by RT-qPCR. The results are presented as the mean \pm SD of three independent experiments. ns, not significant.

https://doi.org/10.1371/journal.ppat.1009434.g005 


\section{Low $\mathrm{pH}$-mediated interaction of $\mathrm{B} 19 \mathrm{~V}$ with $\mathrm{Gb} 4$ initiates active membrane processes}

Multivalent interactions of certain ligands, such as toxins, lectins and viruses with GSLs have been shown to change membrane properties resulting in membrane invaginations and vesicle formation [51-58]. The multimeric configuration of the B19V capsid and the small size of Gb4 would favor multivalent interactions with the GSL and the subsequent changes in membrane properties. To examine the capacity of B19V binding to Gb4 to initiate active membrane processes, we sought to induce the interaction of the virus with Gb4 expressed on UT7/Epo cells. Even though Gb4 is expressed abundantly on the plasma membrane of UT7/Epo cells, the neutral $\mathrm{pH}$ conditions at the cell surface prohibit the interaction. To force the binding to the GSL, WT and $\mathrm{Gb} 4 \mathrm{KO}$ cells were incubated with the virus at $\mathrm{pH} 6.3$ for $1 \mathrm{~h}$ at $37^{\circ} \mathrm{C}$. In WT cells, a 92 -fold average increase in virus attachment was observed at acidic compared to neutral $\mathrm{pH}$. In sharp contrast, the $\mathrm{pH}$ conditions had no significant effect on virus attachment in Gb4 KO cells, confirming that $\mathrm{Gb} 4$ is responsible for the $\mathrm{pH}$-dependent binding enhancement in WT cells (Fig 6A). Virus attachment was also analyzed under VP1uR blocking conditions. To this end, WT and $\mathrm{KO}$ cells were either incubated with functional $(\Delta \mathrm{C} 126)$ or non-functional $(\Delta \mathrm{N} 29$, lacking the RBD) recombinant VP1u (S1A Fig). Subsequently, the cells were incubated with B19V at $37^{\circ} \mathrm{C}$ for $1 \mathrm{~h}$ at $\mathrm{pH} 7.4$ or 6.3. As expected, when VPluR was not blocked, WT and KO cells exhibited a comparable virus binding at $\mathrm{pH} 7.4$, whereas at $\mathrm{pH} 6.3$ virus binding was substantially increased only in WT cells. Under VP1uR blocking conditions, virus attachment was inhibited, except for WT cells at pH 6.3, which represents viruses bound exclusively to Gb4 (Fig 6B).

We next analyzed the capacity of $\mathrm{B} 19 \mathrm{~V}$ bound to $\mathrm{Gb} 4$ to trigger membrane processes resulting in virus uptake. To this end, WT cells were preincubated with recombinant VP1u $\Delta \mathrm{C} 126$ to block VP1uR. Subsequently, the virus was incubated with the cells at $\mathrm{pH} 6.3$ for $1 \mathrm{~h}$ at $4^{\circ} \mathrm{C}$ to allow attachment to $\mathrm{Gb} 4$ or $37^{\circ} \mathrm{C}$ to allow attachment and uptake. After the incubation, the cells were washed with PBS pH 7.4 to detach non-internalized capsids. While most of the viral particles were removed from cells incubated at $4^{\circ} \mathrm{C}$, cells incubated at $37^{\circ} \mathrm{C}$ displayed a strong intracellular accumulation of capsids (Fig 6C).

To examine the capacity of the Gb4-mediated uptake to initiate the infection, viruses were incubated with cells under VP1uR-blocking conditions at $\mathrm{pH} 6.3$ to allow binding to Gb4. Subsequently, NS1 mRNA was quantified after $24 \mathrm{~h}$ by qPCR and the presence of progeny capsids was examined after $72 \mathrm{~h}$ by immunofluorescence. Although there was a modest increase of NS1 mRNA mediated by Gb4 entry (Fig 6D), no capsid proteins were produced after three days (Fig 6E). Expectedly, Gb4-mediated uptake did not result in infection, since the interaction with extracellular Gb4 was induced under conditions that are not expected to occur during the natural infection. However, this experimental approach demonstrated that binding of $\mathrm{B} 19 \mathrm{~V}$ to Gb4 can stimulate active membrane processes similar to those observed with other ligands interacting with GSLs.

VLPs consisting of VP2, lack the entire VP1. Without the VP1u, these particles are unable to recognize the VP1uR and thus cannot be internalized into permissive cells $[32,36]$. These capsids are particularly useful because they allow the study of Gb4 interaction in a more specific way without the interference of the VP1uR.

The pH-dependent interaction of VLPs with WT and Gb4 KO UT7/Epo cells was examined by Western blot with an antibody against VP2. The results showed a low pH-dependent interaction with Gb4 exclusively in WT cells (Fig 7A). This result was corroborated by immunofluorescence microscopy with an antibody against intact capsids (Fig 7B).

We next tested the capacity of VLPs bound to Gb4 to internalize into UT7/Epo cells. Cells were incubated with VLPs at $\mathrm{pH} 6.3$ at $4^{\circ} \mathrm{C}$ or $37^{\circ} \mathrm{C}$. After $1 \mathrm{~h}$, the cells were washed, fixed and 

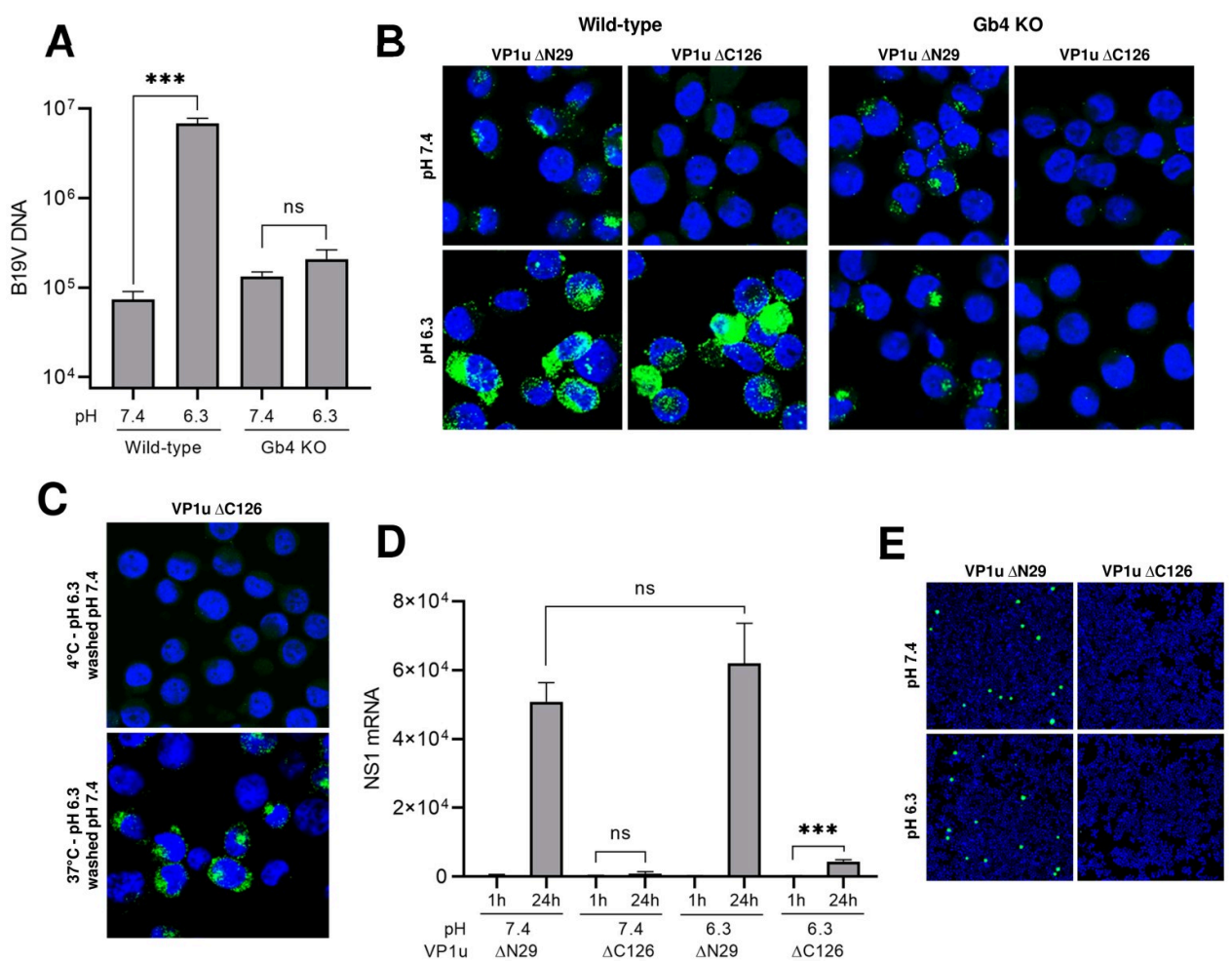

Fig 6. Low $\mathrm{pH}$-mediated interaction of $\mathrm{B} 19 \mathrm{~V}$ with $\mathrm{Gb} 4$ initiates active membrane processes. (A) Quantification of B19V attachment to UT7/Epo WT and Gb4 KO cells at neutral and acidic pH. Cells were infected with B19V ( $10^{4}$ geq/ cell) at $37^{\circ} \mathrm{C}$ for $1 \mathrm{~h}$ followed by four washes. DNA was extracted and quantified by qPCR. The results are presented as the mean \pm SD of three independent experiments. ${ }^{* * *} p<0.001$; ns, not significant. (B) Detection of B19V capsids (86055D) in UT7/Epo WT and Gb4 KO cells under neutral or acidic pH by IF. Cells were incubated for 30 min with functional $(\Delta \mathrm{C} 126)$ to block the VP1uR or non-functional $(\Delta \mathrm{N} 29)$ recombinant VP1u, as a control $(\mathrm{S} 1 \mathrm{Fig})$ at $4^{\circ} \mathrm{C}$. Subsequently, B19V $\left(510^{4} \mathrm{geq} / \mathrm{cell}\right)$ was added for $1 \mathrm{~h}$ at $37^{\circ} \mathrm{C}$. (C) Gb4-mediated uptake of native B19V. Cells were preincubated with functional VP1u $\Delta \mathrm{C} 126$ for $1 \mathrm{~h}$ at $4^{\circ} \mathrm{C}$ prior to infection to block the VP1uR followed by incubation with $\mathrm{B} 19 \mathrm{~V}$ at $4^{\circ} \mathrm{C}$ or $37^{\circ} \mathrm{C}$ for $1 \mathrm{~h}$ at $\mathrm{pH}$ 6.3. Non-internalized virus was removed by a washing step at neutral $\mathrm{pH}$. Internalized viruses were detected by IF with antibody $860-55 \mathrm{D}$ against capsids. (D) Infectivity assay at neutral and acidic $\mathrm{pH}$. WT cells were incubated for $30 \mathrm{~min}$ at $4^{\circ} \mathrm{C}$ with functional recombinant VP1u $(\Delta \mathrm{C} 126)$ to block the VP1uR or non-functional $(\Delta \mathrm{N} 29)$, as a control. Subsequently, B19V $\left(510^{4} \mathrm{geq} / \mathrm{cell}\right)$ was added for $1 \mathrm{~h}$ at $37^{\circ} \mathrm{C}$ in a buffer with the indicated $\mathrm{pH}$. Cells were washed after $1 \mathrm{~h}$ or further incubated for $24 \mathrm{~h}$ at $37^{\circ} \mathrm{C}$. NS1 mRNA was extracted and quantified by RT-qPCR. The results are presented as the mean \pm SD of three independent experiments. ns, not significant. (E) Alternatively, $72 \mathrm{~h}$ post-infection, capsid protein expression was examined by IF with antibody 3113-81C.

https://doi.org/10.1371/journal.ppat.1009434.g006

examined by confocal immunofluorescence microscopy. Pictures taken from the top and the middle sections revealed the presence of internalized capsids in cells incubated at $37^{\circ} \mathrm{C}$, but not at $4^{\circ} \mathrm{C}(\mathrm{Fig} 7 \mathrm{C})$. Alternatively, following $1 \mathrm{~h}$ incubation at $4^{\circ} \mathrm{C}$ or $37^{\circ} \mathrm{C}$, cells were washed with $\mathrm{PBS}$ pH 7.4 to detach non-internalized capsids. While most of the viral particles were removed from cells incubated at $4^{\circ} \mathrm{C}$, cells incubated at $37^{\circ} \mathrm{C}$ displayed a strong intracellular signal (Fig 7D). Collectively, these results confirm that the low $\mathrm{pH}$-mediated interaction of $\mathrm{B} 19 \mathrm{~V}$ with Gb4 is mediated by the VP2 region and induces changes in membrane properties resulting in vesicle formation.

\section{Erythrocytes do not play a significant role as viral decoy targets during B19V infection}

$\mathrm{B} 19 \mathrm{~V}$ can establish high-titer viremia during the acute phase of the infection. Gb4 is the most abundant neutral GSL expressed on RBCs [29,30]. Since RBCs cannot be infected by viruses, 


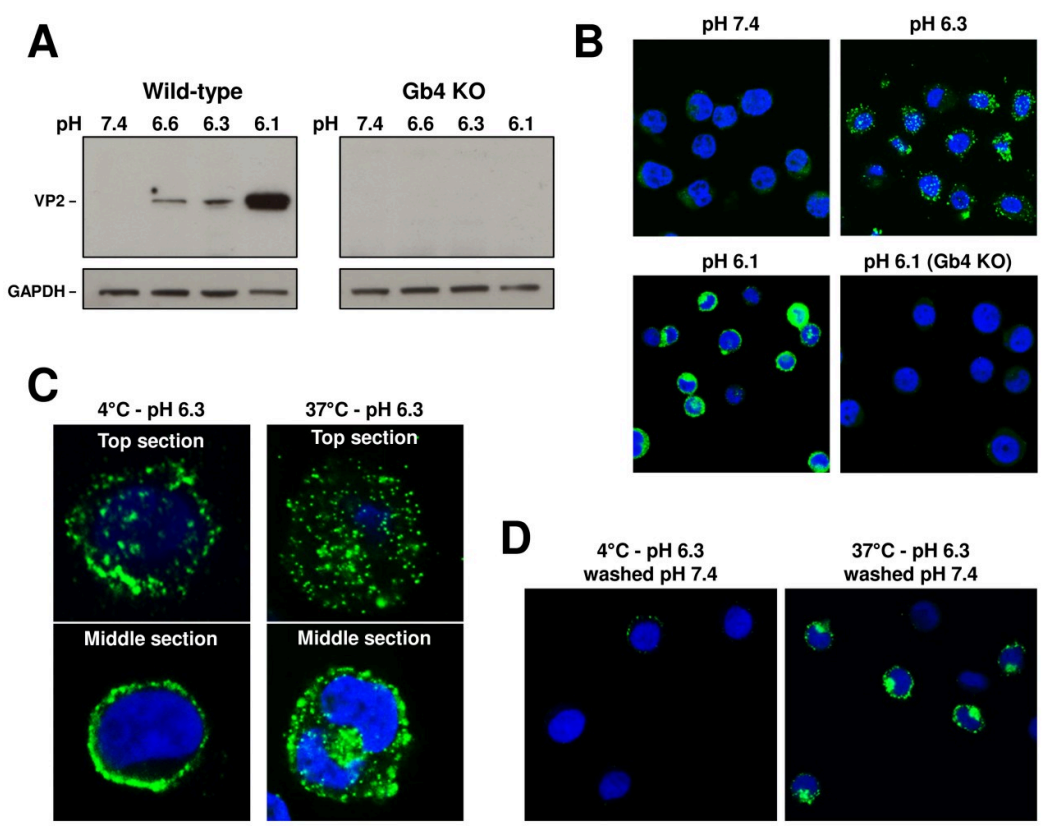

Fig 7. pH-mediated interaction of VP2-only particles with Gb4 triggers the uptake process independently of the VP1uR. (A) Detection of VLPs bound to WT and Gb4 KO UT7/Epo cells at different $\mathrm{pH}$ values by Western blot using antibody $3113-81 \mathrm{C}$. VLPs $\left(10^{10}\right)$ were incubated with cells $\left(3 \times 10^{5}\right)$ at the indicated $\mathrm{pH}$ values for $1 \mathrm{~h}$ at $37^{\circ} \mathrm{C}$. GAPDH expression was used as a loading control. (B) Detection of VLPs (860-55D) in UT7/Epo WT and Gb4 KO cells under neutral or acidic pH by IF. (C) Gb4-mediated uptake of VLPs. Top and middle sections of cells incubated with VLPs at $4^{\circ} \mathrm{C}$ or $37^{\circ} \mathrm{C}$ for $1 \mathrm{~h}$ at $\mathrm{pH}$ 6.3. (D) Gb4-mediated uptake of VLPs. Cells were incubated with VLPs at $4{ }^{\circ} \mathrm{C}$ or $37^{\circ} \mathrm{C}$ for $1 \mathrm{~h}$ at $\mathrm{pH}$ 6.3. Non-internalized virus was removed by a washing step at neutral $\mathrm{pH}$. Internalized particles were detected by IF with antibody $860-55 \mathrm{D}$ against capsids.

https://doi.org/10.1371/journal.ppat.1009434.g007

binding of B19V to Gb4 expressed on erythrocytes would trap the virus and hinder the infection. The interaction of B19V with RBCs was tested in the natural environment of the blood. To this end, B19V was spiked into fresh blood samples ( $\mathrm{pH} 7.4)$ without B19V-specific antibodies. After incubation for $1 \mathrm{~h}$, the erythrocytes were separated from the plasma by centrifugation and washed at neutral pH. As shown in Fig 8A, B19V was consistently found in the plasma fraction in three distinct blood samples. The absence of significant B19V binding to RBCs was further confirmed by immunofluorescence microscopy with an antibody against intact capsids. As expected, decreasing the $\mathrm{pH}$ to 6.3 triggered a substantial binding of the virus to RBCs (Fig 8B). Besides the neutral $\mathrm{pH}$ of the blood, an unknown component(s) of the plasma has been shown to inhibit the hemagglutination activity of B19V [24]. Consistent with this observation, the binding efficiency of B19V to RBCs increased approximately 10 -fold when no blood plasma components were present (Fig 8C). Since the conditions for the interaction with Gb4 are largely suboptimal in the blood, we conclude that despite the abundant expression of Gb4, the erythrocytes do not play a significant role as viral decoy targets during $\mathrm{B} 19 \mathrm{~V}$ viremia.

\section{Discussion}

B19V has a marked tropism for erythroid progenitor cells (EPCs) in the bone marrow [17-19]. The narrow tropism of $\mathrm{B} 19 \mathrm{~V}$ is mediated by multiple factors highly restricted to the Epodependent erythroid differentiation stages [21,59-64]. A virus demanding such strict conditions for replication would also require a selective receptor exclusively expressed in the target cells. This strategy would allow the virus to avoid nonpermissive cells, which have the potential 

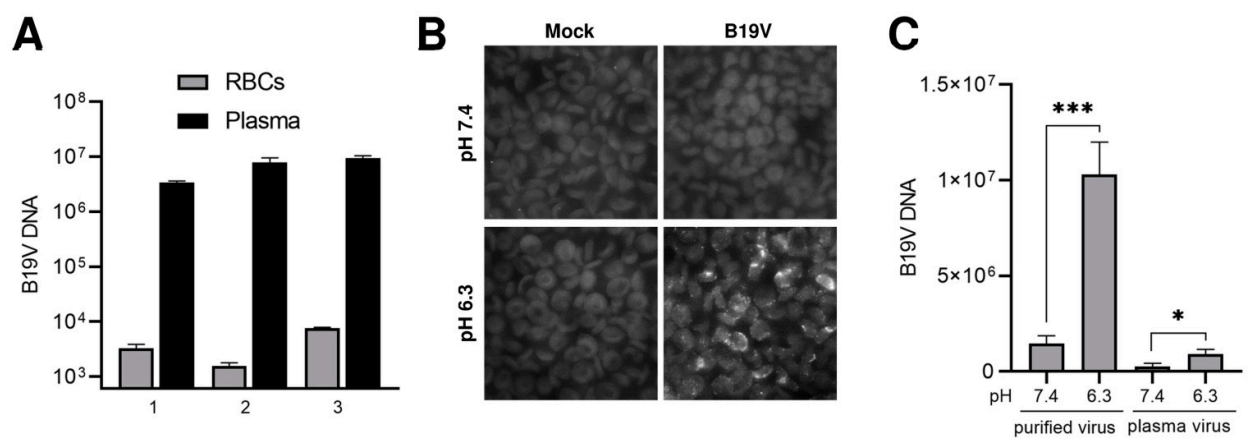

Fig 8. Erythrocytes do not play a significant role as viral decoy targets during B19V viremia. (A) Freshly collected blood samples (with EDTA as anticoagulant) and tested negative for antibodies against B19V, were spiked with B19V $\left(10^{9}\right.$ virions) and incubated for $1 \mathrm{~h}$ at $37^{\circ} \mathrm{C}$. The plasma and the $\mathrm{RBC}$ fractions were separated by centrifugation, the RBCs were washed with PBS (pH 7.4) and the viral DNA was extracted from both fractions and quantified by qPCR. (B) Detection of B19V in the RBC fraction by IF with an antibody against intact capsids (860-55D). (C) A component (s) in human plasma inhibits binding of B19V to RBCs. RBCs $(0.5 \%$ in $100 \mu \mathrm{liBS})$ were incubated at $\mathrm{pH} 7.4$ or 6.3 with $\mathrm{B} 19 \mathrm{~V}\left(5 \times 10^{9}\right)$ directly from an infected plasma sample or after purification by iodixanol density gradient centrifugation. After $1 \mathrm{~h}$ at room temperature, the erythrocytes were washed four times with the corresponding buffer and viral DNA was extracted and quantified. The results are presented as the mean \pm SD of three independent experiments. ${ }^{*}, p<0.05 ;{ }^{* * *}, p<0.001$.

https://doi.org/10.1371/journal.ppat.1009434.g008

to hamper the infection by diverting viruses away from target tissues. The neutral glycosphingolipid (GSL) globoside (Gb4) has been historically considered the primary cellular receptor of $\mathrm{B} 19 \mathrm{~V}[23,26]$. However, Gb4 is not the receptor that would be expected for a virus with the remarkable restricted tropism of B19V. Gb4 is expressed in a multitude of cell types that are not permissive to the infection [27,28], and is the major neutral GSL of RBCs, which cannot support viral infections $[29,30]$. Accordingly, the interaction between the virus and the GSL either does not occur or requires strict conditions.

In an earlier study, we identified a functional RBD in the VP1u region of B19V, which mediates virus attachment and uptake in EPCs through interaction with a yet unidentified receptor, referred to as VP1uR [11,32]. In contrast to the ubiquitous expression of Gb4, VP1uR expression is restricted to EPCs, which are the only cells that B19V can productively infect $[19,32]$. In a follow-up study, we showed that B19V was able to attach and internalize cells expressing VP1uR but lacking Gb4. However, in the absence of Gb4, the internalized virus was unable to initiate the infection [37]. These findings together reveal that VP1uR is the cellular receptor of B19V responsible for the restricted virus uptake in permissive erythroid cells, whereas $\mathrm{Gb} 4$ is an essential factor required at a post-internalization step.

In this study, the mechanism of the interaction of B19V with $\mathrm{Gb} 4$ and the step of the infection where the GSL is required were investigated. We confirmed that the genetic removal of the gene encoding for Gb4 in UT7/Epo cells does not disturb the expression and function of the VP1uR, and consequently, the uptake of B19V is also not affected (Fig 1A-1C). However, Gb4 is required after virus internalization and before the delivery of the ssDNA into the nucleus for replication (Fig $1 \mathrm{D}$ and $1 \mathrm{E}$ ). It has been previously shown that during the first hour following B19V uptake in UT7/Epo cells, the incoming capsids colocalize with endo-lysosomal markers, appearing as a dense perinuclear signal. Subsequently, the virus signal becomes more scattered and colocalization with endocytic markers decreases gradually [40]. As shown in Fig 2A, 30 min post-internalization in WT and Gb4 KO cells, the virus signal colocalizes intensively with endo-lysosomal markers. As expected, $3 \mathrm{~h}$ pi in WT cells, capsid signal becomes more scattered and less co-localized with endo-lysosomal markers. In contrast, in cells lacking Gb4, the virus signal does not progress and remains associated with endosomal 
markers, suggesting a role of Gb4 in the infectious endocytic trafficking of B19V. Furthermore, in Gb4 KO cells, B19V behaves like artificial MS2-VP1u capsids, which are unable to escape from endosomes (Fig 2B and S3 Fig).

The finding that $\mathrm{pH}$ acts as a switch to modulate the affinity between $\mathrm{B} 19 \mathrm{~V}$ and $\mathrm{Gb} 4$ has major implications in the virus tropism, infection and spread. Under neutral conditions, which are characteristic of the extracellular milieu, B19V does not interact with the ubiquitously expressed $\mathrm{Gb} 4$. This strategy prevents the redirection of the virus to nonpermissive tissues facilitating the selective targeting of the EPCs in the bone marrow. We and others observed a strong association of B19V to RBCs in viremic blood samples [35,65]. The blood sample used in our studies was acidic due to anaerobic glycolysis, a process that occurs naturally during blood storage [66]. In the study of Chehadeh et al., the RBCs were washed in acidic PBS and stored in Alsever's solution, which is an acidic solution ( $\mathrm{pH}$ 6.1) routinely used as an anticoagulant and preservative. In other studies, when B19V was spiked into a fresh blood sample to mimic viremia, the virus was mostly associated with the plasma fraction and those found in the RBC fraction were easily removed by a washing step. [67]. This result was confirmed in our studies, where no significant binding to RBCs was observed when B19V was spiked into fresh blood samples with an experimentally verified neutral $\mathrm{pH}$ (Fig 8A and 8B). Besides a suboptimal $\mathrm{pH}$ for $\mathrm{Gb} 4$ binding, blood plasma contains an inhibitor(s) that interferes with hemagglutination (Fig 8C) [24]. Our results revealed that during B19V viremia, the fairly constant neutral $\mathrm{pH}$ of the blood and the presence of an inhibitor(s) hinder the stable binding of the virus to $\mathrm{Gb} 4$ on RBCs, which would otherwise divert the virus with an overwhelming amount of decoy targets and thereby hamper the infection.

The acidic $\mathrm{pH}$ conditions required for the interaction exclude the binding to Gb4 expressed on the plasma membrane, which is typically exposed to neutral $\mathrm{pH}$ conditions. However, Gb4 is also found in intracellular compartments. GSLs are continuously internalized from the cell surface by clathrin-dependent and independent mechanisms in invaginated vesicles. These vesicles fuse with early endosomes, resulting in the glycan component of the GSL facing the vesicle lumen [42,68]. From early endosomes, GSLs can be recycled back to the plasma membrane, transported to the Golgi apparatus or to late endosomes and finally lysosomes where they undergo terminal degradation by specific lysosomal enzymes [42,69-71]. Although B19V is internalized via clathrin-dependent endocytosis [40], and Gb4 is mostly internalized via clathrin-independent endocytosis [42], both reach the early endosomes. The acidic luminal $\mathrm{pH}$ in early endosomes around 6.0 and the depleted $\mathrm{Ca}^{2+}$ levels coincide with the optimal conditions required for the interaction with Gb4 (Fig 4). Accordingly, incoming B19V can potentially interact with Gb4 inside early endosomes as an essential step in the infectious trafficking. In line with this assumption, the absence of Gb4 resulted in endosomal retention of the incoming capsids (Fig 2).

Multivalent interactions of certain ligands, such as bacterial toxins, lectins and viruses, with GSLs trigger membrane curvature and invaginations that ultimately result in vesicle formation [51-58]. In our studies, the interaction under acidic conditions of B19V and VLPs with Gb4 in the exoplasmic membrane leaflet resulted in virus uptake (Figs 6C, 7C and 7D), suggesting that similar active membrane processes are induced by the multivalent binding of the capsid with $\mathrm{Gb} 4$ molecules. Further research will aim to characterize changes in membrane properties mediated by the interaction of the virus with GSL-enriched areas of the endosomal membrane and the influence of additional intracellular factors in the interplay between B19V and Gb4.

In summary, this study provides mechanistic insight into the interaction of B19V with Gb4 and its essential role as an intracellular interacting partner required for infectious trafficking. The finding that $\mathrm{pH}$ acts as an affinity switch to modulate the interaction between the virus and the GSL contributes to a better understanding of B19V restricted tropism, infection and 
spread. In the future, studies will aim at elucidating the precise function of Gb4 in B19V endocytic trafficking, which will deepen our understanding of membrane dynamics induced by the interaction of viruses with GSLs and inspire novel strategies interfering with the early steps of the infection.

\section{Materials and methods}

\section{Cells and viruses}

The human megakaryoblastoid cells UT7/Epo were cultured in Eagle's minimal essential medium (MEM) containing 5\% fetal calf serum (FCS) along with $2 \mathrm{U} / \mathrm{ml}$ recombinant erythropoietin (Epo). Whole blood samples from anonymous donors were washed three times with PBS. Packed red blood cells (RBCs) were resuspended in an equal volume of Alsever's solution ( $4.2 \mathrm{~g} / \mathrm{l} \mathrm{NaCl}, 8 \mathrm{~g} / \mathrm{l}$ sodium citrate, $0.55 \mathrm{~g} / \mathrm{l}$ citric acid, $20.5 \mathrm{~g} / \mathrm{l}$ dextrose) and stored at $4^{\circ} \mathrm{C}$. ExpiSf9 cells for recombinant baculovirus production were cultured at $27^{\circ} \mathrm{C}$ and $125 \mathrm{rpm}$ in ExpiSf CD Medium (Thermo Fisher Scientific, Waltham, MA). B19V-infected plasma sample was obtained from a donation center (CSL Behring AG, Charlotte, NC) and virus concentration $\left(3 \times 10^{9} \mathrm{geq} / \mu \mathrm{l}\right)$ was determined by qPCR. B19V was concentrated by ultracentrifugation through a $20 \%$ sucrose cushion and further purified by iodixanol density gradient ultracentrifugation, as previously described [50]. Plaque-purified MVM was obtained from ATCC (VR1346).

\section{Antibodies}

The human monoclonal antibody $860-55 \mathrm{D}$ against intact capsids was purchased from Mikrogen (Neuried, Germany). The monoclonal mouse antibody 3113-81C (US Biological, Boston, MA) was used for the detection of viral proteins by Western blot as well as for the detection of progeny virus by immunofluorescence. A polyclonal chicken anti-Gb4 IgY antibody was a gift from J. Müthing (University of Münster). Antibodies against late endosomes (M6PR, ab2733), lysosomes (Lamp1, ab25630), cis-Golgi (GM130, ab52649) and GAPDH (ab9485) were obtained from abcam (Cambridge, UK). A rat anti-FLAG monoclonal antibody (200474) was purchased from Agilent (Santa Clara, CA). MS2 capsid proteins were detected with a polyclonal rabbit antibody (ABE76-I, Merck Millipore, France).

\section{Generation of MS2-VP1u bioconjugate}

Fluorescent MS2 VLPs bioconjugated to B19V VP1u were produced as previously described [19]. Briefly, MS2 coat protein or truncated VP1u $(\Delta \mathrm{C} 126 / \Delta \mathrm{N} 29)$ proteins were expressed in E. coli BL21(DE3) cells for $4 \mathrm{~h}$ at $37^{\circ} \mathrm{C}$. Assembled MS2 capsids in cell lysate were purified by ultracentrifugation through a sucrose cushion. Recombinant VP1u was purified twice with nickel nitrilotriacetic acid (Ni-NTA) agarose. Chemical crosslinking between MS2 VLPs and truncated VP1u proteins was carried out in two steps. First, surface lysines on MS2 capsids were modified with fluorescent dyes (NHS-Atto488 or NHS-Atto633) and the heterobifunctional maleimide-PEG24-N-hydroxysuccinimide ester crosslinker (Thermo Fisher Scientific). Second, purified fluorescent maleimide-activated MS2 capsids were incubated with reduced VP1u proteins to achieve bioconjugation. After quenching of the reaction, MS2-VP1u constructs were pelleted by ultracentrifugation.

\section{Production and purification of B19 virus-like particles}

Recombinant B19 virus-like particles (VLPs) consisting of VP2 were produced using the ExpiSf Expression System Starter Kit (Thermo Fisher Scientific) following the manufacturer's 
instructions. Briefly, the B19 VP2 gene was cloned into a pFastBac1 plasmid and used to create recombinant bacmids, which were transfected into ExpiSf9 cells to generate recombinant baculovirus. This virus was able to express VP2 particles by infection of ExpiSf9 cells at a multiplicity of infection of 5. Infected ExpiSf9 cells were lysed 72h pi and the assembled B19 VP2 particles were purified by ultracentrifugation through a sucrose cushion followed by a separation on a sucrose gradient. Positive fractions were identified by dot blot and exchanged into a storage buffer (20 mM Tris-HCl, [pH 7.8], $10 \mathrm{mM} \mathrm{NaCl}, 2 \mathrm{mM} \mathrm{MgCl}$ ) using desalting columns. Quantification of VP2 particles was determined by absorbance at A280 with NanoDrop (NanoDrop2000, Thermo Fisher Scientific), as well as by comparison to a reference B19V sample on a dot blot.

\section{Immunofluorescence}

For surface staining, UT7/Epo cells were incubated at $4^{\circ} \mathrm{C}$ with anti-Gb4 antibody or with anti-FLAG-tag labelled recombinant VP1u prior to fixation. UT7/Epo cells were fixed with a mixture of methanol and acetone $(1: 1)$ at $-20^{\circ} \mathrm{C}$ for $4 \mathrm{~min}$. RBCs were fixed with $1 \%$ glutaraldehyde at room temperature for $10 \mathrm{~min}$. Fixed cells were blocked with $10 \%$ goat-serum prior to staining with antibodies. Bound primary antibodies were detected with secondary antibodies with conjugated Alexa Fluor dyes and analyzed using confocal microscopy (LSM 880, Zeiss, Germany).

\section{Virus binding and internalization}

For each experiment, either UT7/Epo cells $\left(3 \times 10^{5}\right)$ or alternatively a $0.5 \% \mathrm{RBC}$ suspension were prepared in $100 \mu \mathrm{PiBS}$ ( $20 \mathrm{mM}$ piperazine-N,N'-bis[2-ethanesulfonic acid], $123 \mathrm{mM}$ $\mathrm{NaCl}, 2.5 \mathrm{mM} \mathrm{KCl})$ of varying $\mathrm{pH}$ or PBS. B19V was added to UT7/Epo cells $\left(10^{4}\right.$ geq/cell for PCR analysis, $5 \times 10^{4} \mathrm{geq} / \mathrm{cell}$ for immunofluorescence analysis) or to RBCs $\left(5 \times 10^{9}\right)$ and incubated at $4^{\circ} \mathrm{C}$ or $37^{\circ} \mathrm{C}$ for $1 \mathrm{~h}$. Cells were washed 4 times at room temperature. Subsequently, the samples were prepared for immunofluorescence analysis or qPCR. For qPCR, B19V DNA was isolated by the DNeasy Blood \& Tissue Kit (Qiagen, Hilden, Germany) according to the manufacturer's protocol. The following primers were used, forward primer: 5'-GGGGCAGCATGT GTTAA-3'; reverse: 5'- AGTGTTCCAGTATATGGCATGG-3'.

\section{Transfection}

B19V DNA was isolated and quantified as described earlier. The viral DNA was transfected into UT7/Epo cells $\left(2 \times 10^{5}\right)$ seeded one day prior using lipofectamine 3000 reagent (Invitrogen) according to the manufacturer's instructions. B19V NS1 mRNA and viral capsid proteins were analyzed 2 days post infection using immunofluorescence as described above or RT-qPCR. Viral mRNA transcripts were isolated using the Dynabeads mRNA DIRECT Kit (Invitrogen) according to the proposed protocol. Identical primers as indicated above were employed.

\section{NS1 mRNA and capsid protein expression}

Infection of UT7/Epo cells was examined by quantification of viral NS1 mRNA and by immunofluorescence staining of viral proteins. Cells were washed four times $1 \mathrm{~h}$ after virus binding and incubated in medium for up to three days. The cells were harvested and washed four times with PBS. For immunofluorescence analysis the cells were fixed as described above and stained with a monoclonal mouse antibody against the viral capsid proteins followed by staining with a goat anti-mouse IgG Alexa Fluor 488 (Invitrogen). Viral mRNA was extracted and analyzed as described for transfected cells. 


\section{Hemagglutination assay}

RBCs were washed 3 times and brought to a concentration of $1 \%$ in PiBS. Glycosphingolipids (Gb3 [Globotriaosylceramide] and Gb4, Matreya LLC, PA) were dissolved in DMSO (5 mg/ml and $25 \mathrm{mg} / \mathrm{ml}$ respectively) and diluted to the desired concentration immediately before use. When applicable, B19V or VP2 particles $\left(5 \times 10^{9}\right)$ were incubated for $30 \mathrm{~min}$ in $50 \mu \mathrm{l}$ of the indicated buffers along with $\mathrm{Gb} 3 / \mathrm{Gb} 4$ prior to hemagglutination experiments. $50 \mu \mathrm{l} \% \mathrm{RBC}$ solution were then added to each well and incubated for $1 \mathrm{~h}$ at room temperature.

\section{Western blot analysis of VP2 particles binding}

A total of $10^{10} \mathrm{VP} 2$ particles were added to either a $0.5 \% \mathrm{RBC}$ solution or to $3 \times 10^{5} \mathrm{UT} 7 /$ Epo cells in $100 \mu \mathrm{PiBS}$ of varying $\mathrm{pH}$. The cell suspension was incubated for $1 \mathrm{~h}$ at $37^{\circ} \mathrm{C}$. The cells were subsequently washed three times and resuspended in $2 \mathrm{x}$ Laemmli buffer containing $0.1 \mathrm{M}$ dithiothreitol. Samples were boiled and resolved on a 10\% SDS-PAGE and transferred to a PVDF membrane. The membrane was blocked overnight at $4^{\circ} \mathrm{C}$ using $5 \%$ milk in TBS-T. Viral proteins were detected using the same mouse antibody described above followed by farred fluorescent based detection using an $680 \mathrm{RD}$ goat anti-Mouse IgG secondary antibody (LI-COR Biosciences, Lincoln, NE) in the case of RBCs or with chemiluminescent detection using an HRP-conjugate for the UT7/Epo cells.

\section{Cell cycle analysis}

UT7/Epo cells $\left(1.5 \times 10^{5}\right)$ were seeded in $1 \mathrm{ml}$ MEM in a 12-well plate and infected with B19V containing plasma (40'000 geq per cell) or mock infected. Cells were harvested 3 days post infection and washed with PBS containing $1 \%$ albumin (PBSA), resuspended in $300 \mu \mathrm{l}$ PBSA and fixed by dropwise addition of $700 \mu \mathrm{l}$ ethanol cooled to $-20^{\circ} \mathrm{C}$. Tubes were carefully inverted five times stored at $4^{\circ} \mathrm{C}$ for $1 \mathrm{~h}$. The cells were pelleted and washed twice with PBSA. Cells were incubated with $100 \mu \mathrm{g}$ RNase A for $30 \mathrm{~min}$ at $37^{\circ} \mathrm{C}$ and stained with $1 \mu \mathrm{g} 4^{\prime}, 6$-diamidino-2-phenylindole (DAPI). Cells were sorted on a Cytoflex flow cytometer (Beckman Coulter) and analyzed using FCS express 7 (De Novo Software).

\section{Analysis}

Data analysis was performed using GraphPad Prism and presented as the mean of three independent experiments \pm standard deviation (SD). Differences in the binding of B19V to Gb4, NS1 mRNA synthesis, and cell cycle arrest at the G2/M-phase, were evaluated by Student's ttest. A P value less than 0.05 was considered statistically significant.

\section{Supporting information}

S1 Fig. B19V VP1u constructs and engineered MS2 particles. (A) Schematic depiction of the functional $(\Delta \mathrm{C} 126)$ and non-functional $(\triangle \mathrm{N} 29)$ recombinant VP1u constructs. (B) SDS-PAGE of purified recombinant VP1u constructs under reducing conditions. (C) Schematic depiction of an MS2 particle showing Atto fluorophores and VP1u constructs incorporated on the capsid surface. (D) Crosslinking between recombinant MS2 capsid proteins and VP1u constructs was verified by Western blot using an anti-MS2 antibody.

S2 Fig. B19V induces cell cycle arrest in WT but not in Gb4 KO UT7/Epo cells. Cells were fixed 3d pi and cellular DNA was stained with DAPI. Cell cycle progression was analyzed using flow cytometry. The results are presented as the mean \pm SD of three independent 
experiments. ${ }^{* *}, p<0.01$; ns, not significant.

(TIF)

S3 Fig. Quantitative analysis of intracellular fluorescent foci per cell. Cells exhibiting perinuclear cluster of endosomes in focus (encircled by a dotted line) were selected for analysis. Distinct, clearly visible fluorescent spots (B19V capsids; green) not colocalizing with endocytic markers (red) were counted.

(TIF)

S4 Fig. Internalized MS2-VP1u particles remain sequestered inside the endosomes. UT7/ Epo cells $\left(3 \times 10^{5}\right)$ were incubated with $2 \mu$ Atto 488 -labeled MS2-VP1u at $4^{\circ} \mathrm{C}$ for $1 \mathrm{~h}$, washed and further incubated at $37^{\circ} \mathrm{C}$ for $30 \mathrm{~min}$ and $3 \mathrm{~h}$. Cells were fixed and labeled with antibodies against late endosomes (M6PR) and lysosomes (Lamp1) and visualized under confocal microscopy.

(TIF)

S5 Fig. RBCs integrity is not compromised by exposure to mild acidic conditions. Scanning electron microscopy of RBCs exposed to $\mathrm{pH} 7.4$ or 6.3 for $2 \mathrm{~h}$. RBCs were fixed with $1 \%$ glutaraldehyde, dehydrated by subsequent treatment with increasing concentrations of ethanol. Specimen were mounted and analyzed on a scanning electron microscope (Zeiss) with a 100'000-fold magnification. Bar, $10 \mu \mathrm{m}$.

S6 Fig. Purity and integrity of B19 VLPs. (A) Capsid protein purity of VLPs (VP2-only particles) was verified by SDS-PAGE. Capsid integrity was analyzed by electron microscopy (B), and by dot blot hybridization with an antibody against intact capsids (860-55D) (C). Bar; $100 \mu \mathrm{m}$.

S7 Fig. Effect of temperature on the low $\mathbf{p H}$-mediated interaction of B19V with Gb4. RBCs $(0.5 \%$ in $100 \mu \mathrm{l} \mathrm{PiBS})$ were incubated with $\mathrm{B} 19 \mathrm{~V}\left(5 \times 10^{9}\right)$ at $\mathrm{pH} 7.4$ or 6.3 at different temperatures for $1 \mathrm{~h}$. The cells were subsequently washed at room temperature or at $4^{\circ} \mathrm{C}$ and viral DNA was extracted and quantified by qPCR.

(TIF)

S8 Fig. Preincubation of viruses or RBCs separately at acid pH does not support hemagglutination at neutral pH. B19V $\left(5 \times 10^{9}\right)$ and $\mathrm{RBCs}(0.5 \%$ in $100 \mu \mathrm{l} \mathrm{PiBS})$ were incubated separately at acidic $\mathrm{pH}$ for $1 \mathrm{~h}$. Subsequently, the HA was performed at neutral (7.4) of acidic (6.3) $\mathrm{pH}$. HA, hemagglutination assay.

\section{Acknowledgments}

We are grateful to Beatrice Frey for the assistance with the transmission electron microscope.

\section{Author Contributions}

Conceptualization: Jan Bieri, Remo Leisi, Carlos Ros.

Data curation: Jan Bieri, Carlos Ros.

Formal analysis: Jan Bieri, Remo Leisi, Carlos Ros.

Funding acquisition: Carlos Ros. 
Investigation: Jan Bieri, Carlos Ros.

Methodology: Jan Bieri, Remo Leisi, Cornelia Bircher, Carlos Ros.

Project administration: Carlos Ros.

Resources: Carlos Ros.

Supervision: Carlos Ros.

Writing - original draft: Jan Bieri, Carlos Ros.

Writing - review \& editing: Jan Bieri, Remo Leisi, Cornelia Bircher, Carlos Ros.

\section{References}

1. Cossart YE, Cant B, Field AM, Widdows D. Parvovirus-Like Particles in Human Sera. Lancet. 1975; 305: 72-73. https://doi.org/10.1016/s0140-6736(75)91074-0 PMID: 46024

2. Qiu J, Söderlund-Venermo M, Young NS. Human Parvoviruses. Clin Microbiol Rev. 2017; 30: 43 LP113. https://doi.org/10.1128/CMR.00040-16 PMID: 27806994

3. Servey JT, Reamy B V., Hodge J. Clinical presentations of parvovirus B19 infection. Am Fam Physician. 2007; 75. PMID: 17304869

4. Anderson MJ, Jones SE, Fisher-Hoch SP, Lewis E, Hall SM, Bartlett CLR, et al. Human parvovirus, the cause of erythema infectiosum (Fifth disease)? The Lancet. 1983. https://doi.org/10.1016/s0140-6736 (83)92152-9 PMID: 6134148

5. Anderson MJ, Higgins PG, Davis LR, Willman JS, Jones SE, Kidd IM, et al. Experimental parvoviral infection in humans. J Infect Dis. 1985. https://doi.org/10.1093/infdis/152.2.257 PMID: 2993431

6. Bonvicini F, Bua G, Gallinella G. Parvovirus B19 infection in pregnancy-awareness and opportunities. Curr Opin Virol. 2017; 27: 8-14. https://doi.org/10.1016/j.coviro.2017.10.003 PMID: 29096233

7. Chorba T, Coccia P, Holman RC, Tattersall P, Anderson LJ, Sudman J, et al. The role of parvovirus b19 in aplastic crisis and erythema infectiosum (Fifth disease). J Infect Dis. 1986. https://doi.org/10.1093/ infdis/154.3.383 PMID: 3016109

8. Saarinen UM, Chorba TL, Tattersall P. Human parvovirus B-19-induced epidemic acute red cell aplasia in patients with hereditary hemolytic anemia. Blood. 1986. https://doi.org/10.1182/blood.v67.5.1411. 1411 PMID: 3008891

9. Cotmore SF, McKie VC, Anderson LJ, Astell CR, Tattersall P. Identification of the major structural and nonstructural proteins encoded by human parvovirus B19 and mapping of their genes by procaryotic expression of isolated genomic fragments. J Virol. 1986. https://doi.org/10.1128/JVI.60.2.548-557.1986 PMID: 3021988

10. Anderson S, Momoeda M, Kawase M, Kajigaya S, Young NS. Peptides derived from the unique region of B19 parvovirus minor capsid protein elicitneutralizing antibodies in rabbits. Virology. 1995. https://doi. org/10.1016/s0042-6822(95)80079-4 PMID: 7530397

11. Leisi $R$, Di Tommaso $C$, Kempf $C$, Ros $C$. The receptor-binding domain in the VP1u region of parvovirus B19. Viruses. 2016. https://doi.org/10.3390/v8030061 PMID: 26927158

12. Zádori Z, Szelei J, Lacoste MC, Li Y, Gariépy S, Raymond P, et al. A Viral Phospholipase A2 Is Required for Parvovirus Infectivity. Dev Cell. 2001; 1: 291-302. https://doi.org/10.1016/s1534-5807(01) 00031-4 PMID: 11702787

13. Dorsch S, Liebisch G, Kaufmann B, von Landenberg P, Hoffmann JH, Drobnik W, et al. The VP1 Unique Region of Parvovirus B19 and Its Constituent Phospholipase A2-Like Activity. J Virol. 2002; 76: 20142018. https://doi.org/10.1128/jvi.76.4.2014-2018.2002 PMID: 11799199

14. Canaan S, Zádori Z, Ghomashchi F, Bollinger J, Sadilek M, Moreau ME, et al. Interfacial Enzymology of Parvovirus Phospholipases A2. J Biol Chem. 2004; 279: 14502-14508. https://doi.org/10.1074/jbc. M312630200 PMID: 14726513

15. Deng X, Dong Y, Yi Q, Huang Y, Zhao D, Yang Y, et al. The Determinants for the Enzyme Activity of Human Parvovirus B19 Phospholipase A2 (PLA2) and Its Influence on Cultured Cells. PLoS One. 2013; 8. https://doi.org/10.1371/journal.pone.0061440 PMID: 23596524

16. Farr GA, Zhang LG, Tattersall P. Parvoviral virions deploy a capsid-tethered lipolytic enzyme to breach the endosomal membrane during cell entry. Proc Natl Acad Sci U S A. 2005; 102: 17148-17153. https://doi.org/10.1073/pnas.0508477102 PMID: 16284249 
17. Ozawa K, Kurtzman G, Young N, Shimizu A, Honjo T. Replication of the B19 Parvovirus in Human Bone Marrow Cell Cultures. Science. 2016; 233: 883-886. https://doi.org/10.1126/science.3738514 PMID: 3738514

18. Takahashi T, Ozawa K, Takahashi K, Asano S, Takaku F. Susceptibility of human erythropoietic cells to B19 parvovirus in vitro increases with differentiation. Blood. 1990; 75: 603-10. https://doi.org/10.1182/ blood.V75.3.603.603 PMID: 2404522

19. Leisi R, Von Nordheim M, Ros C, Kempf C. The VP1u receptor restricts parvovirus B19 uptake to permissive erythroid cells. Viruses. 2016. https://doi.org/10.3390/v8100265 PMID: 27690083

20. Wong S, Zhi N, Filippone C, Keyvanfar K, Kajigaya S, Brown KE, et al. Ex Vivo-Generated CD36+ Erythroid Progenitors Are Highly Permissive to Human Parvovirus B19 Replication. J Virol. 2008; 82: 2470-2476. https://doi.org/10.1128/JVI.02247-07 PMID: 18160440

21. Chen AY, Guan W, Lou S, Liu Z, Kleiboeker S, Qiu J. Role of Erythropoietin Receptor Signaling in Parvovirus B19 Replication in Human Erythroid Progenitor Cells. J Virol. 2010; 84: 12385-12396. https:// doi.org/10.1128/JVI.01229-10 PMID: 20861249

22. Bua G, Manaresi E, Bonvicini F, Gallinella G. Parvovirus B19 Replication and Expression in Differentiating Erythroid Progenitor Cells. PLoS One. 2016; 11: 1-19. https://doi.org/10.1371/journal.pone. 0148547 PMID: 26845771

23. Brown KE, Anderson SM, Young NS. Erythrocyte $P$ antigen: Cellular receptor for $B 19$ parvovirus. Science (80-). 1993. https://doi.org/10.1126/science.8211117 PMID: 8211117

24. Brown KE, Cohen BJ. Haemagglutination by parvovirus B19. J Gen Virol. 1992. https://doi.org/10.1099/ 0022-1317-73-8-2147 PMID: 1645153

25. Kaufmann B, Baxa U, Chipman PR, Rossmann MG, Modrow S, Seckler R. Parvovirus B19 does not bind to membrane-associated globoside in vitro. Virology. 2005. https://doi.org/10.1016/j.virol.2004.11. 037 PMID: 15661151

26. Brown KE, Hibbs JR, Gallinella G, Anderson SM, Lehman ED, Mccarthy P, et al. Resistance to parvovirus B19 infection due to lack of virus receptor (erythrocyte P antigen). N Engl J Med. 1994. https://doi. org/10.1056/NEJM199404283301704 PMID: 8139629

27. Bailly P, Bouhours JF. P blood group and related antigens. Cartron J.P., Rouger P. (Eds.), Molecular Basis of Major Human Blood Group Antigens, Plenum Press, New York (1995), pp. 299-329.

28. Cooling LLW, Koerner TAW, Naides SJ. Multiple glycosphingolipids determine the tissuetropism of parvovirus b19. J Infect Dis. 1995; 172: 1198-1205. https://doi.org/10.1093/infdis/172.5.1198 PMID: 7594654

29. Naiki M, Marcus DM. Human erythrocyte $P$ and $P k$ blood group antigens: Identification as glycosphingolipids. Biochem Biophys Res Commun. 1974; 60: 1105-1111. https://doi.org/10.1016/0006-291x(74) 90426-4 PMID: 4429565

30. Fletcher KS, Bremer EG, Schwarting GA. P blood group regulation of glycosphingolipid levels in human erythrocytes. J Biol Chem. 1979; 254: 11196-11198. PMID: 500637

31. Weigel-Kelley KA, Yoder MC, Srivastava A. Recombinant Human Parvovirus B19 Vectors: Erythrocyte P Antigen Is Necessary but Not Sufficient for Successful Transduction of Human Hematopoietic Cells. J Virol. 2001. https://doi.org/10.1128/jvi.75.9.4110-4116.2001

32. Leisi R, Ruprecht N, Kempf C, Ros C. Parvovirus B19 Uptake Is a Highly Selective Process Controlled by VP1u, a Novel Determinant of Viral Tropism. J Virol. 2013. https://doi.org/10.1128/JVI.02548-13 PMID: 24067971

33. Leisi R, Von Nordheim M, Kempf C, Ros C. Specific targeting of proerythroblasts and erythroleukemic cells by the VP1u region of parvovirus B19. Bioconjug Chem. 2015; 26: 1923-1930. https://doi.org/10. 1021/acs.bioconjchem.5b00321 PMID: 26240997

34. Ros C, Gerber M, Kempf C. Conformational changes in the VP1-unique region of native human parvovirus $\mathrm{B} 19$ lead to exposure of internal sequences that play a role in virus neutralization and infectivity. $\mathrm{J}$ Virol. 2006; 80. https://doi.org/10.1128/JVI.01435-06 PMID: 17020940

35. Bönsch C, Kempf C, Ros C. Interaction of Parvovirus B19 with Human Erythrocytes Alters Virus Structure and Cell Membrane Integrity. J Virol. 2008; 82: 11784-11791. https://doi.org/10.1128/JVI.0139908 PMID: 18815302

36. Bönsch C, Zuercher C, Lieby P, Kempf C, Ros C. The Globoside Receptor Triggers Structural Changes in the B19 Virus Capsid That Facilitate Virus Internalization. J Virol. 2010; 84: 11737-11746. https://doi. org/10.1128/JVI.01143-10 PMID: 20826697

37. Bieri J, Ros C. Globoside Is Dispensable for Parvovirus B19 Entry but Essential at a Postentry Step for Productive Infection. J Virol. 2019. https://doi.org/10.1128/jvi.00972-19 PMID: 31341051

38. Nasir W, Nilsson J, Olofsson S, Bally M, Rydell GE. Parvovirus B19 VLP recognizes globoside in supported lipid bilayers. Virology. 2014. https://doi.org/10.1016/j.virol.2014.04.004 PMID: 24889255 
39. Chipman PR, Agbandje-Mckenna M, Kajigaya S, Brown KE, Young NS, Baker TS, et al. Cryo-electron microscopy studies of empty capsids of human parvovirus B19 complexed with its cellular receptor. Proc Natl Acad Sci U S A. 1996; 93: 7502-7506. https://doi.org/10.1073/pnas.93.15.7502 PMID: 8755503

40. Quattrocchi S, Ruprecht N, Bonsch C, Bieli S, Zurcher C, Boller K, et al. Characterization of the Early Steps of Human Parvovirus B19 Infection. J Virol. 2012; 86: 9274-9284. https://doi.org/10.1128/JVI. 01004-12 PMID: 22718826

41. Stahnke S, Lux K, Uhrig S, Kreppel F, Hösel M, Coutelle O, et al. Intrinsic phospholipase A2 activity of adeno-associated virus is involved in endosomal escape of incoming particles. Virology. 2011; 409: 7783. https://doi.org/10.1016/j.virol.2010.09.025 PMID: 20974479

42. Puri V, Watanabe R, Singh RD, Dominguez M, Brown JC, Wheatley CL, et al. Clathrin-dependent and -independent internalization of plasma membrane sphingolipids initiates two Golgi targeting pathways. J Cell Biol. 2001; 154: 535-547. https://doi.org/10.1083/jcb.200102084 PMID: 11481344

43. Hilfenhaus S, Cohen BJ, Bates C, Kajigaya S, Young NS, Zambon M, et al. Antibody capture haemadherence tests for parvovirus B19-specific IgM and IgG. J Virol Methods. 1993; 45: 27-37. https://doi. org/10.1016/0166-0934(93)90137-g PMID: 8270653

44. Modi S, Swetha MG, Goswami D, Gupta GD, Mayor S, Krishnan Y. A DNA nanomachine that maps spatial and temporal pH changes inside living cells. Nat Nanotechnol. 2009; 4: 325-330. https://doi.org/ 10.1038/nnano.2009.83 PMID: 19421220

45. Padilla-Parra S, Matos PM, Kondo N, Marin M, Santos NC, Melikyan GB. Quantitative imaging of endosome acidification and single retrovirus fusion with distinct pools of early endosomes. Proc Natl Acad Sci U S A. 2012; 109: 17627-17632. https://doi.org/10.1073/pnas.1211714109 PMID: 23047692

46. Albrecht $\mathrm{T}$, Zhao $\mathrm{Y}$, Nguyen $\mathrm{TH}$, Campbell RE, Johnson JD. Fluorescent biosensors illuminate calcium levels within defined beta-cell endosome subpopulations. Cell Calcium. 2015; 57: 263-274. https://doi. org/10.1016/j.ceca.2015.01.008 PMID: 25682167

47. Scott CC, Gruenberg J. Ion flux and the function of endosomes and lysosomes: PH is just the start: The flux of ions across endosomal membranes influences endosome function not only through regulation of the luminal pH. BioEssays. 2011; 33: 103-110. https://doi.org/10.1002/bies.201000108 PMID: 21140470

48. Simpson AA, Chipman PR, Baker TS, Tijssen P, Rossmann MG. The structure of an insect parvovirus (Galleria mellonella densovirus) at $3.7 \AA$ resolution. Structure. 1998; 6: 1355-1367. https://doi.org/10. 1016/s0969-2126(98)00136-1

49. Cotmore SF, Hafenstein S, Tattersall P. Depletion of Virion-Associated Divalent Cations Induces Parvovirus Minute Virus of Mice To Eject Its Genome in a 3'-to-5' Direction from an Otherwise Intact Viral Particle. J Virol. 2010; 84: 1945-1956. https://doi.org/10.1128/JVI.01563-09 PMID: 19955311

50. Caliaro O, Marti A, Ruprecht N, Leisi R, Subramanian S, Hafenstein S, et al. Parvovirus B19 uncoating occurs in the cytoplasm without capsid disassembly and it is facilitated by depletion of capsid-associated divalent cations. Viruses. 2019; 11. https://doi.org/10.3390/v11050430 PMID: 31083301

51. Römer W, Berland L, Chambon V, Gaus K, Windschiegl B, Tenza D, et al. Shiga toxin induces tubular membrane invaginations for its uptake into cells. Nature. 2007; 450: 670-675. https://doi.org/10.1038/ nature05996 PMID: 18046403

52. Ewers H, Römer W, Smith AE, Bacia K, Dmitrieff S, Chai W, et al. GM1 structure determines SV40induced membrane invagination and infection. Nat Cell Biol. 2010; 12: 11-18. https://doi.org/10.1038/ ncb1999 PMID: 20023649

53. Rydell GE, Svensson L, Larson G, Johannes L, Römer W. Human Gll.4 norovirus VLP induces membrane invaginations on giant unilamellar vesicles containing secretor gene dependent $\alpha 1,2$-fucosylated glycosphingolipids. Biochim Biophys Acta-Biomembr. 2013; 1828: 1840-1845. https://doi.org/10. 1016/j.bbamem.2013.03.016 PMID: 23528203

54. Lakshminarayan R, Wunder C, Becken U, Howes MT, Benzing C, Arumugam S, et al. Galectin-3 drives glycosphingolipid-dependent biogenesis of clathrin-independent carriers. Nat Cell Biol. 2014; 16: 592603. https://doi.org/10.1038/ncb2970 PMID: 24837829

55. Pezeshkian W, Hansen AG, Johannes L, Khandelia H, Shillcock JC, Kumar PBS, et al. Membrane invagination induced by Shiga toxin B-subunit: From molecular structure to tube formation. Soft Matter. 2016; 12: 5164-5171. https://doi.org/10.1039/c6sm00464d PMID: 27070906

56. Kociurzynski R, Beck SD, Bouhon JB, Römer W, Knecht V. Binding of SV40's Viral Capsid Protein VP1 to Its Glycosphingolipid Receptor GM1 Induces Negative Membrane Curvature: A Molecular Dynamics Study. Langmuir. 2019; 35: 3534-3544. https://doi.org/10.1021/acs.langmuir.8b03765 PMID: 30802059

57. Watkins EB, Majewski J, Chi EY, Gao H, Florent JC, Johannes L. Shiga Toxin Induces Lipid Compression: A Mechanism for Generating Membrane Curvature. Nano Lett. 2019; 19: 7365-7369. https://doi. org/10.1021/acs.nanolett.9b03001 PMID: 31538793 
58. Kabbani AM, Raghunathan K, Lencer WI, Kenworthy AK, Kelly CV. Structured clustering of the glycosphingolipid GM1 is required for membrane curvature induced by cholera toxin. Proc Natl Acad Sci U S A. 2020; 117: 14978-14986. https://doi.org/10.1073/pnas.2001119117 PMID: 32554490

59. Pallier C, Greco A, Le Junter J, Saib A, Vassias I, Morinet F. The 3' untranslated region of the B19 parvovirus capsid protein mRNAs inhibits its own mRNA translation in nonpermissive cells. J Virol. 1997; 71: 9482-9489. https://doi.org/10.1128/JVI.71.12.9482-9489.1997

60. Brunstein J, Soderlund-Venermo M, Hedman K. Identification of a novel RNA splicing pattern as a basis of restricted cell tropism of erythrovirus B19. Virology. 2000; 274: 284-291. https://doi.org/10.1006/viro. 2000.0460 PMID: 10964772

61. Gallinella G, Manaresi E, Zuffi E, Venturoli S, Bonsi L, Bagnara GP, et al. Different patterns of restriction to B19 parvovirus replication in human blast cell lines. Virology. 2000; 278: 361-367. https://doi.org/10. 1006/viro.2000.0673 PMID: 11118359

62. Guan W, Cheng F, Yoto Y, Kleiboeker S, Wong S, Zhi N, et al. Block to the Production of Full-Length B19 Virus Transcripts by Internal Polyadenylation Is Overcome by Replication of the Viral Genome. J Virol. 2008; 82: 9951-9963. https://doi.org/10.1128/JVI.01162-08 PMID: 18684834

63. Chen AY, Kleiboeker S, Qiu J. Productive parvovirus B19 infection of primary human erythroid progenitor cells at hypoxia is regulated by STAT5A and MEK signaling but not HIFa. PLoS Pathog. $2011 ; 7$. https://doi.org/10.1371/journal.ppat.1002088 PMID: 21698228

64. Wolfisberg R, Ruprecht N, Kempf C, Ros C. Impaired genome encapsidation restricts the in vitro propagation of human parvovirus B19. J Virol Methods. 2013; 193: 215-225. https://doi.org/10.1016/j. jviromet.2013.06.003 PMID: 23764418

65. Chehadeh W, Halim MA, Al-Nakib W. Antibody-mediated opsonization of red blood cells in parvovirus B19 infection. Virology. 2009; 390: 56-63. https://doi.org/10.1016/j.virol.2009.04.016 PMID: 19450862

66. Verma M, Dahiya K. Effect of Blood Storage on Complete Biochemistry. J Blood Disord Transfus. 2015; 06: 8-11. https://doi.org/10.4172/2155-9864.1000329

67. Lee T, Kleinman SH, Wen L, Montalvo L, Todd DS, Wright J, et al. Persistence of Virus in Blood Donors. 2013; 51: 1896-1908. https://doi.org/10.1111/j.1537-2995.2010.03035.x Distribution PMID: 21303368

68. Van Meer G, Voelker DR, Feigenson GW. Membrane lipids: Where they are and how they behave. Nat Rev Mol Cell Biol. 2008; 9: 112-124. https://doi.org/10.1038/nrm2330 PMID: 18216768

69. Sharma DK, Choudhury A, Singh RD, Wheatley CL, Marks DL, Pagano RE. Glycosphingolipids internalized via caveolar-related endocytosis rapidly merge with the clathrin pathway in early endosomes and form microdomains for recycling. J Biol Chem. 2003; 278: 7564-7572. https://doi.org/10.1074/jbc. M210457200 PMID: 12482757

70. Schulze H, Sandhoff K. Lysosomal lipid storage diseases. Cold Spring Harb Perspect Biol. 2011; 3: 119. https://doi.org/10.1101/cshperspect.a004804 PMID: 21502308

71. D'Angelo G, Capasso S, Sticco L, Russo D. Glycosphingolipids: Synthesis and functions. FEBS J. 2013; 280: 6338-6353. https://doi.org/10.1111/febs.12559 PMID: 24165035 